\title{
Article
}

\section{Real Economy Effects on Consumption-Based CAPM}

\author{
Dandan Zheng ${ }^{1,2}$, Shusheng Ding ${ }^{1, *}$, Tianxiang Cui ${ }^{3, *}(\mathbb{D})$ and Huan Jin ${ }^{3}$ \\ 1 Business School, Ningbo University, Ningbo 315201, China; zhengdd@nbtvu.net.cn \\ 2 Teaching Center, Ningbo Open University, Ningbo 315016, China \\ 3 School of Computer Science, University of Nottingham Ningbo China, Ningbo 315104, China; \\ huan.jin@nottingham.edu.cn \\ * Correspondence: dingshusheng@nbu.edu.cn (S.D.); tianxiang.cui@nottingham.edu.cn (T.C.)
}

Citation: Zheng, D.; Ding, S.; Cui, T.; Jin, H. Real Economy Effects on Consumption-Based CAPM. Mathematics 2022, 10, 360. https:// doi.org/10.3390/math10030360

Academic Editor: Manuel Alberto M. Ferreira

Received: 7 December 2021

Accepted: 20 January 2022

Published: 25 January 2022

Publisher's Note: MDPI stays neutral with regard to jurisdictional claims in published maps and institutional affiliations.

Copyright: (C) 2022 by the authors. Licensee MDPI, Basel, Switzerland. This article is an open access article distributed under the terms and conditions of the Creative Commons Attribution (CC BY) license (https:// creativecommons.org/licenses/by/ $4.0 /)$.

\begin{abstract}
The consumption-based capital asset pricing model (CCAPM) is an attractive research field in finance, and extant studies have examined the impacts of different factors towards traditional CCAPM, intending to improve the model from the practical perspective. In this paper, we comprehensively scrutinize the real economy effects on the CCAPM by comprising expenditure on durable, expenditure on non-durable goods, services, and real estate four factors. Our study pays great attention to the real economy effect on the CCAPM based on two types of portfolios. By employing both time-series and cross-sectional analysis, our empirical results suggest that the real economy factors can help traditional CCAPM to produce better asset pricing results. Particularly, incorporating the real estate component into the CCAPM model can improve its explanation power on the stock market risk. Our results are potentially useful for investors, portfolios managers and policy makers towards the CCAPM.
\end{abstract}

Keywords: consumption-based capital asset pricing model (CCAPM); durable goods; non-durable goods; real estate; portfolio management; time-series regression; cross-sectional regression

\section{Introduction}

There is a consensus in asset pricing literature that risky assets and portfolios shall bring higher return for investors who are risk averse. Since Sharpe (1964) [1] and Lintner (1965) [2] introduced the Capital Asset Pricing Model (CAPM), plenty of constraint conditions and assumptions for the model have been demonstrated. For example, no transaction cost assumption of CAPM may not be valid in reality [3]. Furthermore, the observed turbulences in stock markets across developed and developing countries has shortchanged financial investors to consider risks in consumption market, which is also a vital factor in macroeconomics [4]. Since CAPM considers massive number of restriction conditions, Fama and French (2004) [5] reveal the fact that "the failure of the CAPM in empirical tests implies that most applications of the model are invalid". Afterwards, researchers surged to improve this classical model from the practical perspective such as CCAPM. Lucas (1978) [6] introduces a standardized consumption-based CAPM (CCAPM), proposing "a theoretical examination of the stochastic behavior of equilibrium asset prices in a one-good, pure exchange economy with identical consumers". The key virtue of CCAPM is the reconstruction of beta comparing with traditional CAPM [7]. Specifically, beta is a measurement of systematic risk for a specified asset or the portfolio, also known as market beta in CAPM. In contrast, in CCAPM, beta is defined as consumption beta which measures the value of systematic risk. In CCAPM, the definition of consumption beta is the covariance of stock's return and per capita consumption [8]. This consumption beta is not only restructuring the meaning of systematic risk, but it also provides practical insights for economists to undertake empirical studies in reality [9].

It should be noted that CCAPM has performed unsatisfactorily in empirical research in recent years [10-12]. Despite its plausibility, there can be other alternative measures 
of systematic risk. Yum, Charles, and Dong (2014) [13] offer a new insight on systematic risk. They confirm that consumption-based CAPM is robust in the housing market in Hong Kong. Campbell and Akhtar (2000) [14] also find that systematic skewness is economically important and co-skewness is helpful in explaining the cross-sectional variation of equity returns. Abhyankar et al. (2015) [15] verify the significance of CCAPM and cross-sectional variation in influencing the return of US bonds by introducing two periods of uncertainties: current consumption and long-term consumption.

In addition to the above-mentioned aspects, this paper contributes to the CCAPM literature on risk explanation in a number of ways. First of all, we introduce real estate as a factor that may influence the excess return of the stock portfolios. Though real estate is a main element in the consumption of residents in US, few scholars have conducted research regarding it as an important factor in influencing the stock market in US. In this paper, we extend the factors that influence the consumption growth by adding private consumption factors: durable goods, non-durable goods, services, and residential fixed investment in US. The model shows different results by adding these factors one by one. Secondly, since real estate is a vital element, we obtain the data from two sources: one is directly from the figure of residential fixed investment in the Gross Domestic Product charts form National Income and Product Accounts (NIPA), the other is from the mortgage data of all commercial banks. Though the figures that we obtain from these two measures are slightly different, they provide a comprehensive understanding of the influence of the real estate market on stock market. Thirdly, for a better understanding of the influence of stock portfolios, we chose 2 methods, forming 25 portfolios: 1 is sorted on size and book-to-market ratio, the other is sorted on size and short-term reversal. In brief, our model is different from traditional CCAPM by adding real estate factor and different selections of portfolios.

Our main test steps can be listed as follows. Using the 25 portfolios' returns retrieved from Fama/French Data Library, we calculate the excess return per monthly by subtracting the risk-free rate. Then we obtain the quarterly growth rates of the nondurable goods, durable goods, services, and real estate, respectively. Since the stock portfolios' excess returns are monthly and consumption growth rates are quarterly data, we transform the monthly excess returns into quarterly excess returns. Then, we run the time-series regressions on the stock excess returns and the consumption growth rates. As a result, we obtain 25 betas. Using these 25 betas, we run the cross-sectional regression.

This article provides a comprehensive analysis on stock market risk between residual consumptions and real estate consumption in US. In line with the majority of research, we find that the consumption of nondurable goods, durable goods, and services all affect the excess returns of the stock portfolios. Meanwhile, real estate is also an important factor that highly correlated with the excess return of the stock portfolios. Additionally, adding more factors can make the CCAPM more effective. Empirically, it documents that the effectiveness is more significant in 25 portfolios sorted on size and short-term reversal.

More importantly, our contributions to the relation between stock market and the real estate market are twofold. Firstly, extant literature demonstrates that the real estate market leads the stock market in the short run and the long run, implying the credit-price effect between the two markets (see Okunev et al., 2000 [16]; Benjamin et al., 2017 [17]). Our study includes this dynamic relation as a market risk into the CCAPM beta, suggesting a systematic risk measure of such relation. Moreover, we provide an empirical study to verify this credit-price effect and risk measure by illustrating that the real estate asset exhibits a substantially positive effect through the consumption channel under the CCAPM framework.

It has been widely noted that real estate's influence on consumption shall be emphasized. Nevertheless, how real estate influences the stock market through the channel of consumption has no unanimous answer. Our paper sheds the lights on this issue with a number of research implications. First, our paper builds the connection between the real estate market and the stock market. Based on the CCAPM model, we incorporate the real estate investment as one of the capital asset pricing factors. We thereby can unveil the 
interaction between the real estate market and the stock market. This model would be extremely useful for those emerging markets, such as China, implementing the housing monetization reform since 1998, to reveal the new interrelations between the two markets after the reform.

Secondly, we reveal the fact that the transmission channels that real estate investment impacts on capital asset pricing rests on the consumption. It thereby strengthens the argument that the consumption would be frustrated by the real estate investment. We demonstrate that this consumption obstruction would have a considerable effect on the capital asset pricing, and we can quantify such effect via our CCAPM model.

Finally, we constitute a risk measure to comprise the mortgage risk into the asset pricing model. We exhibit that the CCAPM beta that includes the mortgage risk would be more effective than the traditional CCAPM beta. More importantly, this mortgage risk can be reflected in the CCAPM model, which would be extraordinarily helpful in indicating the shocks from the real estate investment towards the capital market. In practice, this risk measure can illuminate the systematic risk in financial system, such as the subprime mortgage crisis in 2008.

The article is organized as follows. In Section 2, we present a literature review of related works. In Section 3, we demonstrate and derive the main results of the proposed model. Empirical results are presented in Section 4; in this section, we also discuss the insights obtained from proposed model. We conclude the paper in Section 5 and discuss future research avenues.

\section{Related Literature}

CCAPM has long been a recurrent topic in finance because it is simple and easy to interpret its economical meaning. Parker and Julliard (2005) [18] argue that the main idea of CCPAM 'that consumption risk is an important determinant of average returns across stocks.' There is mounting evidence that consumption influences excess return in financial market both in a single period and in inter-period. That is to say, most scholars pay attention to the time period of the model. However, the empirical results are a bit mixed across markets, as we briefly review the CCAPM model influence and our own proposed consumption-based view on the traditional CCAPM in the next sections [19].

Economists reached a consensus on the matter that CCAPM discloses limited empirical relationships with the cross-sectional return. Some factors, such as long-run durable expenditure, may not be present in the CCAPM, but in the measurement of consumption used to assess the asset-pricing model [20].

Yogo (2006) [21] has made a model that explains the relationship between stock returns and nondurable and durable consumption; it concludes that 'big stocks and growth stocks have lower nondurable and durable consumption betas than small stocks and value stocks. However, he only pays attention to financial market. With the increasing importance of real estate aspect in capital assets, researchers also introduce housing in the utility function and in the budget constrain. Piazzesi, Schneider and Tuzel (2007) [22] firstly modeled housing as both an asset and a consumption good in a consumption-based asset pricing model which combine financial market with real estate. They enrich the model with "nonhousing consumption and housing expenditure" and conclude that asset market data can better predict the future excess returns than the dividend yield in the financial market. Although they combine real estate expenditure and nonhousing consumption with the stock market, the time period they use is not suitable for research. Due to the influence of world war II (1939-1945), the figures before the year of 1945 are not that significant for practical research. Thus, we improve the efficiency of the data and lengthen the time period to 2021. Yum, Charles, and Dong (2014) [13] develop eight variants of CCAPM with the asset market data from Hong Kong; they draw the conclusion that housing is a specific risk factor in consumption risk in Hong Kong.

One reason for few works about housing market and stock market by using the CCAPM is that some papers treat real estate expenditure as durables. Yogo (2006) [21], as 
well as Chen, Hong and Ren (2016) [23], divides consumption into two aspects: durable goods and nondurable goods. Thus, the definition of durable goods and nondurable goods consumption should be clearly listed, and real estate is not contained in durable goods. Based on the above theoretical justifications and empirical evidence, we define the consumption in four aspects: durable goods, nondurable goods, services, and real estate, since these four aspects almost cover all the consumption of a household.

CCAPM is an asset pricing model proposed by a number of scholars by including the impact of consumption into the asset pricing model (Chen 2003 [9]; Liu, Luo and Zhao, 2015 [10]; Alizadeh et al., 2021 [24]), which is an extension of traditional CAPM model (Balcilar, Demirer and Bekun, 2021 [25]; Peng, Chen and Wei, 2021 [26]). Real estate impact on consumption has been witnessed in the literature (Benjamin et al., 2004 [17]; Piazzesi, Schneider and Tuzel, 2007 [22]; Bostic et al., 2009 [27]; Chen et al., 2020 [28]). This study fills the research gap by demonstrating that real estate contributes the asset pricing betas through the channel of consumption under the CCAPM framework. Our paper also complements the existing literature by providing empirical evidence on the CCAPM model by incorporating the real estate impact.

Accordingly, we develop the main hypothesis based on the existing studies under the CCAPM framework. Azar (2017) [29] indicates that risk aversion is different in the short run and the long run is strong and investors will be willing to accept less risk in the long run, unless they are compensated by a sufficiently higher return premium. Carmichael and Coën (2016) [30] verify that real estate is a vital factor for the cross-sectional variation of returns in the last two decades in US by using a linear multifactor pricing model. For investors, real estate investment belongs to long-term investment, and long-term investment is considered to have greater risks. Dusha and Janiak (2018) [31] study the dynamics of liquidity and asset prices which is the also exists in the real estate industry. It concludes that in a recession since the buyers and sellers have different consumption intentions, the liquidity of commodities is greatly reduced, resulting in a longer time for the sale of real estate. Therefore, in this paper, we assume that there is a positive relationship between real estate and capital market. The change in the real estate market can explain the return in capital market and promote it positively.

Accordingly, we develop our main hypothesis as:

Hypothesis 1. The real estate price would have a positive effect on the return of capital assets in financial markets.

\section{Methodology and Data}

In this section, we build our model based on Capital Asset Pricing Model (CAPM). The main aim is to obtain the maximum utility for whole time, thus we introduce the Intertemporal Capital Asset Pricing Model (ICAPM) at first, which was released by Merton in 1969. Then, we import four factors of consumption growth (durable goods, nondurable goods, services, and real estate) into ICAPM and then obtain traditional CCAPM to expand the utility of the model.

In this model, we assume that the agent attempts to obtain the maximization of lifetime utility function with respect to consumption function and investment function. Moreover, the agent invests a\% of his wealth in stock market and (1-a) \% in risk-free market. Time is divided into a number of small intervals with equal length. Suppose we have a risk-free rate $R_{F}$, and $\mu_{i}-R_{F}$ is defined as the market price of consumption risk. $\mu_{M}-R_{F}$ is defined as excess return over the risk-free rate. Beta, as the amount of exposure to the risk captured by $\left(\mu_{M}-R_{F}\right)$ in the expected return-beta representation of the linear factor model, are estimated from the time-series regressions.

$$
\mu_{\mathrm{i}}-\mathrm{R}_{\mathrm{F}}=\beta_{\mathrm{ic}}\left(\mu_{\mathrm{M}}-\mathrm{R}_{\mathrm{F}}\right)
$$


Equation (1) is the expression of CCAPM. It clearly shows the relationship between the agent's ability to afford goods and services and investment returns. We make a detailed explanation to the model in the following:

(a) The core idea of CCAPM is that consumption expenditure should be covered by the wealth increased in the future. In other words, the risk premium on an asset should equal to its consumption risk. The most important difference between CAPM and CCAPM is the definition of portfolio: in CCAPM, consumption tracking portfolio plays the role of market portfolio in CAPM;

(b) The sensitivity of stock market to consumption market is described as $\beta$. Differing from CAPM, the value of $\beta$ is not necessary. According to much empirical evidence, the value of $\beta$ is usually greater than 1 .

Our model shows that higher risk premium in stock market leads to less expenditure in consumption market. Furthermore, when a lower rewards from the investment, the better choice is to spend more. Just as Breeden (1979) [32] said, higher value of beta leads to higher expected return rate.

The sample we collected is on a quarterly basis, ranging from 1952 Q1 to 2021 Q1. As in Jagannathan and Wang (2007) [33], we collect data from NIPA. Firstly, we use the personal nondurable goods and service quarterly expenditure seasonally adjusted annual rate from Table 2.3.5 of NIPA (this table is from the website of NIPA and does not belong to this paper, and the table number is according to the aforementioned website). Since seasonally unadjusted data are not retrievable from the database, it is also the reason we use seasonally adjusted data. Secondly, we collect population number from Table 2.1 of NIPA (this table is from the website of NIPA and does not belong to this paper, and the table number is according to the aforementioned website), and price deflator series from Table 2.3.4 of NIPA (this table is from the website of NIPA and does not belong to this paper, and the table number is according to the aforementioned website) to convert the normal consumption data into real consumption figures. The stock market data are entirely obtained from Fama/French database. We use monthly average value weighted returns on 25 portfolios formed using 2 measures, and monthly risk-free return from Fama/French 3 factors. For real estate data, we collect them in two ways: one is from the residual consumption of investment in housing, which is collected from NIPA; and the other is the mortgage data from all the banks, which is collected from the household finance data program in Board of Governors of the Federal Reserve System. Since the data of consumption are measured in quarters, we convert monthly excess returns into quarterly returns.

Then, the paper is divided into 2 parts: the first part uses the 25 portfolios sorted on size and book-to-market ratio to run the time-series regression and cross-sectional regression with the consumption data, and the second part uses the 25 size and short-term reversal sorted portfolios to run the time-series regression and cross-sectional regression.

\section{Baseline Results}

\subsection{Portfolios Sorted on Size and Book-to-Market Ratio}

In the following, we discuss the average excess returns of the portfolios in the first place.

Table 1 shows that small companies with low book-to-market ratio, which is called small growth firms, realize an average excess return of $4.83 \%$ per annual, while small companies with high book-to-market ratio, which is called small value firms, earn $13.68 \%$ average excess return for every year. However, in big companies, low book-to-market firm realizes an average excess return of $7.77 \%$ per annual compared to $8.91 \%$ in high bookto-market corporations. It is obviously that-value-growth effect is much more efficient in small companies than in big firms. That is to say, small value firms convey more risk than others and in consequence, they should provide more returns for investors. 
Table 1. Average Annual Excess Return.

\begin{tabular}{cccccc}
\hline & Low & \multicolumn{3}{c}{ Book-to-Market } & High \\
\hline \multirow{2}{*}{ Small } & $4.83 \%$ & $10.38 \%$ & $9.84 \%$ & $12.38 \%$ & $13.68 \%$ \\
& $6.96 \%$ & $10.24 \%$ & $11.00 \%$ & $11.11 \%$ & $12.65 \%$ \\
\multirow{2}{*}{ Size } & $7.93 \%$ & $10.24 \%$ & $9.77 \%$ & $11.35 \%$ & $12.08 \%$ \\
& $8.65 \%$ & $8.67 \%$ & $9.61 \%$ & $10.52 \%$ & $10.61 \%$ \\
Big & $7.77 \%$ & $7.33 \%$ & $8.48 \%$ & $6.99 \%$ & $8.91 \%$ \\
\hline
\end{tabular}

In Table 2 Panel A lists the average values and standard deviations of real consumption growth rate of different factors. $\Delta \mathrm{C}_{\mathrm{n}}$ is the growth rate of nondurable goods and services. $\Delta C_{n s d}$ is the growth rate of nondurable goods, durable goods, and services. $\Delta C_{n s d r}$ is the growth rate of nondurable goods, durable goods, services, and investment in real estate. $\Delta \mathrm{C}_{\mathrm{nsdm}}$ is the growth rate of nondurable goods, durable goods, services, and housing mortgage. All these figures are expressed as percentages.

Table 2. Descriptive Statistics.

\begin{tabular}{|c|c|c|c|c|}
\hline \multicolumn{5}{|c|}{ Panel A: Consumption Growth } \\
\hline & $\Delta \mathrm{C}_{\mathrm{ns}}(\%)$ & $\Delta \mathrm{C}_{\mathrm{nsd}}(\%)$ & $\Delta \mathrm{C}_{\mathrm{nsdr}}(\%)$ & $\Delta \mathrm{C}_{\mathrm{nsdm}}(\%)$ \\
\hline Mean & 0.0266 & 0.0250 & 0.0229 & 0.0252 \\
\hline SD & 0.0162 & 0.0160 & 0.0128 & 0.0182 \\
\hline \multicolumn{5}{|c|}{ Panel B: Consumption Beta } \\
\hline & $\beta_{\mathrm{R}, \mathrm{c}}^{\mathrm{ns}}$ & $\beta_{\mathrm{R}, \mathrm{c}}^{\mathrm{nsd}}$ & $\beta_{\mathrm{R}, \mathrm{c}}^{\mathrm{nsdr}}$ & $\beta_{\mathrm{R}, \mathrm{c}}^{\mathrm{nsdm}}$ \\
\hline Mean & 2.1783 & 3.8714 & 1.3410 & 3.4729 \\
\hline SD & 0.6031 & 0.5890 & 0.4348 & 0.8292 \\
\hline
\end{tabular}

In Table 2 Panel B indicates the mean values and standard deviations for consumption betas. $\beta_{\mathrm{R}, \mathrm{C}}^{\text {ns }}$ is the consumption beta containing factors of nondurable goods and services. $\beta_{\mathrm{R}, \mathrm{c}}^{\text {nsd }}$ is the consumption beta with factors of nondurable goods, durable goods, and services. $\beta_{\mathrm{R}, \mathrm{c}}^{\mathrm{nsdr}}$ is the consumption beta including factors of nondurable goods, durable goods, services and investment in real estate. $\beta_{\mathrm{R}, \mathrm{c}}^{\mathrm{nsdm}}$ is the consumption beta on factors of nondurable goods, durable goods, services and housing mortgage. They are all numerical.

Secondly, the consumption growth and betas can be learned from Table 2. Panel A shows that by adding the influencing factors, the mean of consumption growth decreases gradually from 0.0266 to $0.0252 \%$, and the standard deviation also grows from 0.0162 to $0.0182 \%$. It means that as more factors are added, the consumption growth is more volatile than fewer factors are contained. Panel B indicates that the value of beta declines as influencing factors increase. When there are only 2 factors (nondurable goods and services) containing in the model, the mean of beta is 2.1783 , while it is 3.8714 when we add durable goods and housing investment factors in the model. Similarly, the standard deviation of beta also shifts from 1.3410 to 3.4729 as the factors adding from 2 to 4 . It demonstrates that changes in these four factors can better reflect changes in stock market than less influencing factors.

Thirdly, consumption betas calculated with different factors are being listed in Table 3 . All these consumption betas are estimated by time-series regression:

$$
R_{i}-R_{F}=\alpha_{i}+\beta_{R, i} \Delta C+\varepsilon_{i}
$$

where $R_{i}$ is the return on the portfolios, $R_{F}$ is the risk-free rate, and $\Delta C$ is the real growth of consumption calculated quarterly. 
Table 3. Consumption betas calculated with two factors: firm size and book-to-market-value.

\begin{tabular}{|c|c|c|c|c|c|}
\hline & Low & \multicolumn{3}{|c|}{ Book-to-Market } & High \\
\hline \multicolumn{6}{|c|}{ Panel A : Consumption Betas $\left(\beta_{\mathrm{R}, \mathrm{c}}^{\mathrm{ns}}\right)$} \\
\hline \multirow[t]{4}{*}{ Small } & $1.6433^{* * *}$ & $1.4597 *$ & $2.0740 * *$ & $2.1216^{* *}$ & $2.2142 * * *$ \\
\hline & $(0.0090)$ & $(0.0510)$ & $(0.0130)$ & $(0.0140)$ & $(0.0040)$ \\
\hline & $1.5575^{* *}$ & $1.8114^{* *}$ & $2.2687^{* *}$ & $2.4092^{* * *}$ & $2.9062 * * *$ \\
\hline & $(0.0300)$ & $(0.0330)$ & $(0.0150)$ & $(0.0100)$ & $(0.0000)$ \\
\hline \multirow{5}{*}{ Size } & $1.5721^{* *}$ & $2.0218^{* *}$ & $2.3435 * *$ & $2.8423^{* * *}$ & $2.8763 * * *$ \\
\hline & $(0.0490)$ & $(0.0340)$ & $(0.0220)$ & $(0.0040)$ & $(0.0010)$ \\
\hline & 1.3334 & $2.0732 * *$ & $2.8664^{* * *}$ & $3.0756^{* * *}$ & $2.8762 * * *$ \\
\hline & $(0.1320)$ & $(0.0420)$ & $(0.0070)$ & $(0.0020)$ & $(0.0010)$ \\
\hline & 0.6255 & 1.9048 & $2.3269 *$ & $3.0818^{* * *}$ & $2.1716^{* *}$ \\
\hline \multirow[t]{2}{*}{ Big } & $(0.5730)$ & $(0.1240)$ & $(0.0710)$ & $(0.0050)$ & $(0.0200)$ \\
\hline & & l B : Const & on Betas ( $\beta$ & & \\
\hline \multirow[t]{4}{*}{ Small } & $2.6363^{* * *}$ & $2.6560^{* * *}$ & $3.6221^{* * *}$ & $3.6785^{* * *}$ & $3.7442^{* * *}$ \\
\hline & $(0.0000)$ & $(0.0010)$ & $(0.0000)$ & $(0.0000)$ & $(0.0000)$ \\
\hline & $2.6324^{* * * *}$ & $3.2268^{* * *}$ & $3.9527^{* * *}$ & $4.5849^{* * *}$ & $4.2967^{* * *}$ \\
\hline & $(0.0010)$ & $(0.0010)$ & $(0.0000)$ & $(0.0000)$ & $(0.0000)$ \\
\hline \multirow{5}{*}{ Size } & $2.8490^{* * *}$ & $3.8537^{* * *}$ & $4.3420 * * *$ & $4.7639 * * *$ & $4.2210^{* * *}$ \\
\hline & $(0.0010)$ & $(0.0000)$ & $(0.0000)$ & $(0.0000)$ & $(0.0000)$ \\
\hline & $2.7554^{* * * *}$ & $3.7569 * * *$ & $4.8373^{* * *}$ & $5.3526^{* * *}$ & $4.3391^{* * *}$ \\
\hline & $(0.0050)$ & $(0.0010)$ & $(0.0000)$ & $(0.0000)$ & $(0.0000)$ \\
\hline & $2.8930 * *$ & $4.3105^{* * *}$ & $4.5499 * * *$ & $5.0528^{* * *}$ & $3.8782^{* * *}$ \\
\hline \multirow[t]{2}{*}{ Big } & $(0.0180)$ & $(0.0020)$ & $(0.0010)$ & $(0.0000)$ & $(0.0000)$ \\
\hline & & $1 \mathrm{C}:$ Consu & on Betas $(\beta$ & & \\
\hline \multirow[t]{4}{*}{ Small } & $1.1042^{* *}$ & $1.0709 *$ & $1.4080^{* *}$ & $1.5741^{* *}$ & $1.6488^{* * *}$ \\
\hline & $(0.0270)$ & $(0.0710)$ & $(0.0340)$ & $(0.0210)$ & $(0.0080)$ \\
\hline & 0.7889 & 1.0619 & 1.3411 * & $1.8202 * *$ & $1.8200^{* * *}$ \\
\hline & $(0.1670)$ & $(0.1160)$ & $(0.0690)$ & $(0.0150)$ & $(0.0050)$ \\
\hline \multirow{5}{*}{ Size } & 0.8214 & 1.0013 & $1.3806^{*}$ & $1.4816^{*}$ & $1.8065^{* * *}$ \\
\hline & $(0.1950)$ & $(0.1860)$ & $(0.0880)$ & $(0.0570)$ & $(0.0100)$ \\
\hline & 0.5310 & 0.7796 & 1.5380 * & $1.7567^{* *}$ & $1.8166^{* * *}$ \\
\hline & $(0.4500)$ & $(0.3350)$ & $(0.0670)$ & $(0.0280)$ & $(0.0080)$ \\
\hline & 0.6625 & 0.9950 & 1.2684 & $2.1822^{* *}$ & $1.8669^{* *}$ \\
\hline \multirow[t]{2}{*}{ Big } & $(0.4510)$ & $(0.3110)$ & $(0.2150)$ & $(0.0120)$ & $(0.0120)$ \\
\hline & & D : Consu & n Betas ( $\beta$ & & \\
\hline \multirow[t]{5}{*}{ Small } & $2.1918^{* * * *}$ & $2.1554^{* * *}$ & $3.1015^{* * *}$ & $3.1704^{* * *}$ & $3.3376^{* * *}$ \\
\hline & $(0.0020)$ & $(0.0100)$ & $(0.0010)$ & $(0.0010)$ & $(0.0000)$ \\
\hline & $2.1510^{* * *}$ & $2.7077^{* * *}$ & $3.5758^{* * *}$ & $4.0995^{* * *}$ & $4.0058^{* * *}$ \\
\hline & $(0.0070)$ & $(0.0040)$ & $(0.0010)$ & $(0.0000)$ & $(0.0000)$ \\
\hline & $2.4571^{* * *}$ & $3.3409 * *$ & $3.9366^{* * *}$ & $4.3774^{* * *}$ & $3.8885^{* * *}$ \\
\hline \multirow{4}{*}{ Size } & $(0.0060)$ & $(0.0020)$ & $(0.0010)$ & $(0.0000)$ & $(0.0000)$ \\
\hline & $2.3657^{* *}$ & $3.1182^{* * *}$ & $4.4607^{* * *}$ & $4.9066^{* * *}$ & $4.1415^{* * *}$ \\
\hline & $(0.0170)$ & $(0.0060)$ & $(0.0000)$ & $(0.0000)$ & $(0.0000)$ \\
\hline & $2.6322^{* *}$ & $3.7378^{* * *}$ & $4.3739 * * *$ & $4.8046^{* * *}$ & $3.7834^{* * *}$ \\
\hline Big & $(0.0330)$ & $(0.0070)$ & $(0.0020)$ & $(0.0000)$ & $(0.0000)$ \\
\hline
\end{tabular}

Note: significance levels are denoted by ${ }^{*}, * *, * *$, which correspond to the $10 \%, 5 \%$, and $1 \%$ levels, respectively.

The results of Equation (2) are listed in Table 3. Compared with Tables 1 and 2, we conclude from Table 3 that corporations with a lower return on average tend to have smaller consumption betas, which is similar to the conclusion of Jagannathan and Wang (2007) [33]. Meanwhile, all these betas are almost all significant under the confidence level of $95 \%$. It implies that there is a linear relationship between consumption growth and excess return. Furthermore, it verifies the core idea of CCAPM that the risk on consumption can reflect the changes in stock market. Besides, by comparing with the values of beta, we find that adding 
more consumption factors in the model enhance the relationship between consumption market and stock market, even though it is very slightly.

\subsection{Portfolios Sorted on Size and Short-Term Reversal}

In order to have a clear look at the effects of portfolios that influence the relationship between stock market and consumption market, we choose 25 portfolios formed on size and short-term reversal in Fama French data library to test.

As stated above, Table 4 lists average excess return of the portfolios. At first glance, we find that as short-term reversal gets higher, average annual excess return becomes lower. Meanwhile when the scale of firm becomes bigger and bigger, average annual excess return gets lower and lower. For instance, the average annual excess return of a firm with low short-term reversal and small size is $16.39 \%$, while it is $6.41 \%$ in a big and high short-term reversal company. Compared with Table 1 , someone may doubt that-value-growth effect is wrong according to this table; however, Table 4 confirms value-growth effect. As stated by Fama French, these portfolios are "the intersections of 5 portfolios formed on size and 5 portfolios are formed on prior $(t-1)$ return". It means that a company with low shortterm reversal is a value firm, and a high short-term reversal firm can be considered as a growth company. Thus, a small value firm is considered to pay more excess return than others, which is the same conclusion drawing from Table 1. In other words, value-growth effect is correct in stock market.

Table 4. Average excess return of 25 portfolios formed on size and short-term reversal in Fama French data library.

\begin{tabular}{cccccc}
\hline & Low & \multicolumn{3}{c}{ Short-Term Reverse } & High \\
\hline \multirow{2}{*}{ Small } & $16.39 \%$ & $12.58 \%$ & $11.73 \%$ & $10.12 \%$ & $2.81 \%$ \\
& $15.41 \%$ & $14.93 \%$ & $12.12 \%$ & $10.10 \%$ & $6.18 \%$ \\
Size & $14.34 \%$ & $13.34 \%$ & $11.84 \%$ & $9.39 \%$ & $6.37 \%$ \\
& $13.66 \%$ & $13.92 \%$ & $11.53 \%$ & $9.42 \%$ & $6.14 \%$ \\
Big & $9.73 \%$ & $10.37 \%$ & $9.19 \%$ & $8.65 \%$ & $6.41 \%$ \\
\hline
\end{tabular}

Before we run the time-series regression, we list the mean and standard deviations of consumption betas with different factors in Table 5 .

Table 5. Descriptive Statistics of consumption betas with different factors of 25 portfolios formed on size and short-term reversal in Fama French data library.

\begin{tabular}{ccccc}
\hline & $\beta_{\mathbf{R}, \mathbf{c}}^{\text {ns }}$ & $\beta_{\mathbf{R}, \mathbf{c}}^{\text {nsd }}$ & $\beta_{\mathbf{R}, \mathbf{c}}^{\text {nsdr }}$ & $\beta_{\mathbf{R}, \mathbf{c}}^{\text {nsdm }}$ \\
\hline Mean & 2.0842 & 0.3760 & 1.2459 & 3.3859 \\
SD & 0.3835 & 0.0491 & 0.2892 & 0.4818 \\
\hline
\end{tabular}

According to Table 5, we find that as we add more factors in the model, both the average value and standard deviation of consumption beta becomes smaller. It means that adding more factors makes the fluctuation of the model gradually becomes smaller. There is a little difference between Tables 2 and 5. In Table 2, the value of mean and standard deviation of $\beta_{R, c}^{\text {nsdm }}$ is much smaller than others, while in Table 5 , this is not the case. It is smaller than $\beta_{R, c^{\prime}}^{\text {ns }}$ but it is much bigger than $\beta_{R, c}^{\text {nsd }}$. The reason may be the data of mortgage we collect, which is a little different from investment in housing. Since home mortgage is one part of financial accounts of United States reported in board of governors of the Federal Reserve System while investment in housing is a part of Gross Domestic Product of US announced by Bureau of Economic Analysis. Due to different statistical caliber between two departments, we find these figures are slightly different though they should be the same in the theory.

For a better understanding the relationship between stock market and consumption market, we run time-series regression to obtain consumption betas in the third place. The results are listed in Table 6. 
Table 6. Consumption betas calculated with two factors: firm size and Short-term reversal.

\begin{tabular}{|c|c|c|c|c|c|}
\hline & Low & \multicolumn{3}{|c|}{ Short-Term Reversal } & High \\
\hline \multicolumn{6}{|c|}{ Panel A : Consumption Betas $\left(\beta_{\mathrm{R}, \mathrm{c}}^{\mathrm{ns}}\right)$} \\
\hline \multirow[t]{5}{*}{ Small } & $2.1904^{* * *}$ & $2.0562^{* * *}$ & $1.7665^{* *}$ & $1.8950 * *$ & 1.1029 \\
\hline & $(0.0000)$ & (0.0070) & $(0.0300)$ & $(0.0230)$ & (0.1410) \\
\hline & $2.0597 * * *$ & $2.1443^{* * *}$ & $1.9706^{* *}$ & $1.9734^{* *}$ & $1.8604^{* * *}$ \\
\hline & $(0.0020)$ & $(0.0100)$ & $(0.0250)$ & $(0.0330)$ & $(0.0240)$ \\
\hline & $2.5047^{* * *}$ & $2.4888^{* * *}$ & $2.5651^{* * *}$ & $2.3512 * *$ & $1.9416^{* * *}$ \\
\hline \multirow[t]{4}{*}{ Size } & $(0.0000)$ & $(0.0060)$ & $(0.0080)$ & $(0.0190)$ & $(0.0350)$ \\
\hline & $2.8191^{* * *}$ & $2.2757^{* *}$ & $2.3503^{* *}$ & $2.1280 *$ & $2.3094^{* *}$ \\
\hline & $(0.0000)$ & $(0.0180)$ & $(0.0250)$ & $(0.0510)$ & $(0.0170)$ \\
\hline & $2.5023^{* * *}$ & $2.1604^{* *}$ & 1.3109 & 1.5630 & 1.8164 \\
\hline \multirow[t]{2}{*}{ Big } & $(0.0050)$ & $(0.0480)$ & $(0.2880)$ & $(0.2080)$ & $(0.1220)$ \\
\hline & \multicolumn{5}{|c|}{ Panel B : Consumption Betas $\left(\beta_{\mathrm{R}, \mathrm{c}}^{\text {nsd }}\right)$} \\
\hline \multirow[t]{4}{*}{ Small } & $0.3114^{* * *}$ & $0.3557^{* * *}$ & $0.3320 * * *$ & $0.3570^{* * *}$ & $0.2433^{* * *}$ \\
\hline & $(0.0000)$ & $(0.0000)$ & $(0.0000)$ & $(0.0000)$ & $(0.0030)$ \\
\hline & $0.3094^{* * *}$ & $0.3875^{* * *}$ & $0.3875^{* * *}$ & $0.3865^{* * *}$ & $0.3217^{* * *}$ \\
\hline & $(0.0000)$ & $(0.0000)$ & $(0.0000)$ & $(0.0000)$ & $(0.0000)$ \\
\hline \multirow{5}{*}{ Size } & $0.3578^{* * *}$ & $0.4263^{* * *}$ & $0.4483^{* * *}$ & $0.4196^{* * *}$ & $0.3492^{* * *}$ \\
\hline & $(0.0000)$ & $(0.0000)$ & $(0.0000)$ & $(0.0000)$ & $(0.0010)$ \\
\hline & $0.3916^{* * *}$ & $0.3904^{* * *}$ & $0.4596^{* * *}$ & $0.4024^{* * *}$ & $0.3985^{* * *}$ \\
\hline & $(0.0000)$ & $(0.0000)$ & $(0.0000)$ & $(0.0010)$ & $(0.0000)$ \\
\hline & $0.3509^{* * *}$ & $0.4193^{* * *}$ & $0.4010^{* * *}$ & $0.4444^{* * *}$ & $0.3483^{* * *}$ \\
\hline \multirow[t]{2}{*}{ Big } & $(0.0000)$ & $(0.0000)$ & $(0.0030)$ & $(0.0010)$ & $(0.0070)$ \\
\hline & & C: Consu & n Betas $(\beta$ & & \\
\hline \multirow[t]{4}{*}{ Small } & $1.3313^{* * *}$ & $1.4184^{* *}$ & $1.2289 *$ & $1.2442 *$ & 0.6842 \\
\hline & $(0.0080)$ & $(0.0180)$ & $(0.0570)$ & $(0.0600)$ & $(0.2490)$ \\
\hline & $1.3144^{* *}$ & $1.5432 * *$ & 1.2297 * & 1.3447 * & 1.0128 \\
\hline & $(0.0140)$ & $(0.0190)$ & $(0.0790)$ & $(0.0660)$ & (0.1210) \\
\hline \multirow{5}{*}{ Size } & $1.4228^{* *}$ & $1.4688^{* *}$ & $1.5244^{* *}$ & 0.9976 & 0.9660 \\
\hline & $(0.0120)$ & $(0.0420)$ & $(0.0480)$ & $(0.2100)$ & $(0.1870)$ \\
\hline & $1.6324^{* * * *}$ & 1.1048 & 1.2242 & 0.9612 & 0.9096 \\
\hline & $(0.0080)$ & $(0.1480)$ & $(0.1420)$ & $(0.2680)$ & $(0.2380)$ \\
\hline & $1.7436^{* *}$ & $1.6078^{*}$ & 1.5803 & 1.0219 & 0.6310 \\
\hline \multirow[t]{2}{*}{ Big } & $(0.0130)$ & $(0.0630)$ & $(0.1060)$ & $(0.2990)$ & $(0.4980)$ \\
\hline & & $1 \mathrm{D}:$ Consur & on Betas $(\beta$ & & \\
\hline \multirow[t]{5}{*}{ Small } & $2.6070^{* * * *}$ & $3.1598^{* * *}$ & $2.8998^{* * *}$ & $3.1335^{* * *}$ & $2.1956^{* * *}$ \\
\hline & $(0.0000)$ & $(0.0000)$ & $(0.0010)$ & $(0.0010)$ & $(0.0090)$ \\
\hline & $2.5538^{* * *}$ & $3.3506^{* * *}$ & $3.3318 * * *$ & $3.5828^{* * *}$ & $2.9986^{* * *}$ \\
\hline & $(0.0010)$ & $(0.0000)$ & $(0.0010)$ & $(0.0000)$ & $(0.0010)$ \\
\hline & $3.0700^{* * *}$ & $3.8211^{* * *}$ & $4.0304^{* * *}$ & $3.7664^{* * *}$ & $3.3286^{* * *}$ \\
\hline \multirow{4}{*}{ Size } & $(0.0000)$ & $(0.0000)$ & $(0.0000)$ & $(0.0010)$ & $(0.0010)$ \\
\hline & $3.4973^{* * *}$ & $3.4826^{* * *}$ & $4.0439 * * *$ & $3.6127^{* * *}$ & $3.7160 * * *$ \\
\hline & $(0.0000)$ & $(0.0010)$ & $(0.0010)$ & $(0.0030)$ & $(0.0010)$ \\
\hline & $3.2110^{* * *}$ & $4.0572^{* * *}$ & $3.8213^{* * *}$ & $4.0211^{* * *}$ & $3.3547^{* * *}$ \\
\hline Big & $(0.0010)$ & $(0.0010)$ & $(0.0050)$ & $(0.0040)$ & $(0.0100)$ \\
\hline
\end{tabular}

Note: significance levels are denoted by ${ }^{*}, * *, * *$, which correspond to the $10 \%, 5 \%$, and $1 \%$ levels, respectively.

In Table 6, we draw the same conclusions that as more and more factors are contained; the value of consumption beta gets smaller and smaller within the same size and short-term reversal firm. Meanwhile all of them are significant under the confidence level of $95 \%$, which means that the model is correct and suitable.

In conclusion, no matter which kind of portfolios are formed, they are all correlated with consumption factors, such as consumption of nondurable goods, durable goods, services and real estate. Meanwhile as we add more factors in the traditional CCAPM, the values of beta are much smaller which means that the model is more practical. In order to 
have a deep sight in the relationship between consumption betas and stock excess returns, we run the cross-sectional regression in the next section.

\section{Further Empirical Results}

We estimate our model using an alternative methodology: cross-sectional regressions with univariate betas. In part 4 we run the time-series regressions and estimate univariate betas for each model. In this part, we run the cross-sectional regressions of average excess returns on the estimated betas, and we estimate the loadings related to risk factors, gamma $\gamma_{1}$ :

$$
\mathrm{R}_{\mathrm{p}, \mathrm{t}}-\mathrm{R}_{\mathrm{f}, \mathrm{t}}=\gamma_{0}+\gamma_{1} \beta_{\mathrm{R}_{\mathrm{p}, \mathrm{c}}}+\epsilon_{\mathrm{R}_{\mathrm{p}} \mathrm{t}}
$$

where $R_{p, t}$. is the return on portfolio $p$ at time $t, R_{f, t}$ is risk-free rate at time $t, \beta_{R_{p}, c}$ is the consumption beta, which is presented in Table 3.

Betas, estimated in the first stage represent the riskiness of the assets-the quantities of risk related to specific risk factors, and they are directly proportional to covariance of test assets excess returns with risk factors. The factor loadings, estimated in the second stage, are interpreted as risk prices associated with specific risk factors.

In this section, we further discuss the influence of these four factors on traditional CCAPM. Firstly, we study the different effects of portfolios formed in different factors. Secondly, we learn the effects of stock market which can also be formed in various ways.

\subsection{Effects of Real Economy Factors}

In this part, we exam the consumption factors that influence final results in two kinds of portfolios. Table 7 shows the cross-sectional regression results on adjusted R-squares under the conditions of different factors based on the portfolios formed on size and book-tomarket ratio.

It indicates that, in the overwhelming majority of cases, the values of adjusted RSquare increase slightly when more factors are added. For example, adjusted R-square is $16.30 \%$ in the traditional CCAPM, while it increases to $21.30 \%$ when the consumption of durable goods factor is added. Since investment in real estate is put in, adjusted R-square grows to $18.80 \%$. Moreover, when we use the value of mortgage from all commercial banks as another way to indicate residential consumption in housing, adjusted R-square is $27.30 \%$.

At the same time, Table 8 has shown the same result by using the size and short-term reversal formed portfolios.

We further exhibit the results of Tables 7 and 8 in Figures 1 and 2. Specifically, Figure 1 displays the comparison between different models based on the portfolios formed on size and book-to-market ratio. Since there are two ways to signature the effect of real estate on CCAPM, it is been divided into two panels (Panel A and Panel B) to show the results.

In addition, Figure 2 displays the comparison between different models based on the portfolios formed on size and short-term reversal. Since there are two ways to sig-nature the effect of real estate on CCAPM, it is been divided into two panels (Panel A and Panel B) to show the results. 
Table 7. Cross-sectional regression results on adjusted R-squares under the conditions of different factors based on the portfolios formed on size and book-to-market ratio.

\begin{tabular}{|c|c|c|c|c|c|c|c|c|c|c|}
\hline Traditional CCAPM & $\begin{array}{c}0.1011 \text { ** } \\
(0.1630)\end{array}$ & $\begin{array}{c}0.0473 \\
(0.0470)\end{array}$ & $\begin{array}{l}-0.0644 \\
(0.0510)\end{array}$ & $\begin{array}{c}0.0528 \\
(0.0570)\end{array}$ & $\begin{array}{c}0.0701 \\
(0.0690)\end{array}$ & $\begin{array}{c}-0.0715^{* *} \\
(0.1630)\end{array}$ & $\begin{array}{l}-0.0164 \\
(0.0080)\end{array}$ & $\begin{array}{c}0.0529 \\
(0.0210)\end{array}$ & $\begin{array}{c}0.0337 \\
(0.0520)\end{array}$ & $\begin{array}{l}0.0801 * \\
(0.1470)\end{array}$ \\
\hline \multirow[t]{2}{*}{ Durable Goods } & $0.1514^{* *}$ & 0.095 & -0.0627 & 0.1110 * & -0.0561 & 0.108 & -0.0247 & 0.0496 & 0.0663 & $0.0758 *$ \\
\hline & $(0.2130)$ & $(0.1100)$ & $(0.0280)$ & $(0.1480)$ & $(0.0400)$ & $(0.0960)$ & $(0.0110)$ & $(0.0420)$ & $(0.0190)$ & $(0.1530)$ \\
\hline \multirow[t]{2}{*}{ Durable Goods and Real Estate } & $0.0784^{* *}$ & 0.0276 & -0.0643 & 0.0498 & 0.0007 & $0.0662 *$ & $-0.0791^{* * *}$ & -0.0434 & 0.015 & 0.0243 \\
\hline & $(0.1880)$ & $(0.0310)$ & $(0.0970)$ & $(0.0980)$ & $(0.0000)$ & $(0.1180)$ & $(0.3840)$ & $(0.1060)$ & $(0.0030)$ & $(0.0520)$ \\
\hline \multirow[t]{2}{*}{ Durable Goods and Mortgage } & $0.1800^{* *}$ & 0.1133 * & -0.0855 & $0.1384^{* *}$ & -0.0783 & 0.1412 * & -0.0366 & 0.0503 & 0.0768 & $0.0829 * *$ \\
\hline & $(0.2730)$ & $(0.1410)$ & $(0.0470)$ & $(0.2080)$ & $(0.0700)$ & $(0.1480)$ & $(0.0230)$ & $(0.0390)$ & $(0.0230)$ & $(0.1660)$ \\
\hline \multirow{2}{*}{ Traditional CCAPM } & -0.0101 & -0.0207 & 0.0308 & -0.0035 & $0.0728 * *$ & -0.04 & 0.0252 & 0.0267 & -0.029 & $-0.1083^{* *}$ \\
\hline & $(0.0020)$ & $(0.0300)$ & $(0.0370)$ & $(0.0000)$ & $(0.2820)$ & $(0.0780)$ & $(0.0330)$ & $(0.0200)$ & $(0.0100)$ & $(0.3370)$ \\
\hline \multirow[t]{2}{*}{ Durable Goods } & -0.0213 & 0.0094 & -0.0374 & -0.1108 & 0.0625 * & $-0.0887^{* *}$ & 0.0007 & 0.0363 & -0.0399 & $-0.1300^{* *}$ \\
\hline & $(0.0050)$ & $(0.0040)$ & $(0.0310)$ & $(0.1060)$ & $(0.1220)$ & $(0.2230)$ & $(0.0000)$ & $(0.0220)$ & $(0.0110)$ & $(0.2830)$ \\
\hline \multirow[t]{2}{*}{ Durable Goods and Real Estate } & 0.0028 & $-0.0443^{* *}$ & 0.0163 & 0.0397 & $0.0643^{* * *}$ & -0.0264 & 0.0235 & 0.0237 & -0.0108 & $-0.0742^{* *}$ \\
\hline & $(0.0000)$ & $(0.2620)$ & $(0.0200)$ & $(0.0450)$ & $(0.4240)$ & $(0.0650)$ & $(0.0550)$ & $(0.0310)$ & $(0.0030)$ & $(0.3040)$ \\
\hline \multirow[t]{2}{*}{ Durable Goods and Mortgage } & -0.0315 & 0.0023 & -0.046 & -0.0968 & $0.0762 * *$ & $-0.0956^{* *}$ & -0.0084 & 0.0512 & -0.0376 & $-0.1430 * *$ \\
\hline & $(0.0100)$ & $(0.0000)$ & $(0.0430)$ & $(0.0730)$ & $(0.1640)$ & $(0.2350)$ & $(0.0020)$ & $(0.0390)$ & $(0.0090)$ & $(0.3100)$ \\
\hline \multirow[t]{2}{*}{ Traditional CCAPM } & $0.1045^{* * *}$ & $0.1134^{* *}$ & $0.1057^{*}$ & $-0.1019 *$ & 0.0177 & 0.0046 & 0.0227 & 0.0101 & -0.0034 & 0 \\
\hline & $(0.5110)$ & $(0.1950)$ & $(0.1370)$ & $(0.1260)$ & $(0.0130)$ & $(0.0000)$ & $(0.0110)$ & $(0.0090)$ & $(0.0010)$ & $(0.0000)$ \\
\hline \multirow[t]{2}{*}{ Durable Goods } & $0.1244^{* * *}$ & $0.1764^{* *}$ & 0.1238 & -0.0911 & -0.0415 & $0.1147^{*}$ & -0.0515 & -0.0326 & $-0.0546^{*}$ & 0.04 \\
\hline & $(0.4240)$ & $(0.2750)$ & $(0.1100)$ & $(0.0590)$ & $(0.0420)$ & $(0.1170)$ & $(0.0320)$ & $(0.0530)$ & $(0.1470)$ & $(0.0150)$ \\
\hline \multirow[t]{2}{*}{ Durable Goods and Real Estate } & $0.0715^{* * *}$ & $0.0814^{* *}$ & $0.0818^{* *}$ & $-0.1202 * *$ & 0.0111 & 0.0071 & 0.0152 & 0.0183 & 0.0063 & -0.0146 \\
\hline & $(0.4600)$ & $(0.1930)$ & $(0.1570)$ & $(0.3370)$ & $(0.0100)$ & $(0.0010)$ & $(0.0090)$ & $(0.0550)$ & $(0.0060)$ & $(0.0070)$ \\
\hline \multirow[t]{2}{*}{ Durable Goods and Mortgage } & $0.1288^{* * *}$ & $0.2012^{* *}$ & $0.1360 *$ & -0.112 & -0.0517 & $0.1193 *$ & -0.0507 & 0.0183 & $-0.0604^{* *}$ & 0.0331 \\
\hline & $(0.4110)$ & $(0.3240)$ & $(0.1200)$ & $(0.0800)$ & $(0.0590)$ & $(0.1140)$ & $(0.0280)$ & $(0.0550)$ & $(0.1620)$ & $(0.0100)$ \\
\hline \multirow[t]{2}{*}{ Traditional CCAPM } & -0.0331 & $0.0459^{* *}$ & $-0.0307^{*}$ & -0.0029 & -0.0638 & -0.0879 & $-0.0471^{* *}$ & -0.0393 & $0.0546^{* *}$ & $0.0610^{* *}$ \\
\hline & $(0.1070)$ & $(0.1590)$ & $(0.1220)$ & $(0.0000)$ & $(0.0770)$ & $(0.0970)$ & $(0.1930)$ & $(0.0480)$ & $(0.2610)$ & $(0.1710)$ \\
\hline \multirow[t]{2}{*}{ Durable Goods } & $-0.0828^{* * *}$ & $0.1019 * * *$ & $-0.0701 * *$ & 0.0242 & -0.0814 & -0.0592 & $-0.0985^{* * *}$ & -0.0025 & $0.1074^{* * *}$ & $0.1234^{* * *}$ \\
\hline & $(0.3900)$ & $(0.4580)$ & $(0.3710)$ & $(0.0090)$ & $(0.0730)$ & $(0.0260)$ & $(0.4930)$ & $(0.0000)$ & $(0.5890)$ & $(0.4090)$ \\
\hline \multirow[t]{2}{*}{ Durable Goods and Real Estate } & -0.0225 & 0.0195 & -0.0161 & -0.0224 & -0.0374 & $-0.0863^{* *}$ & -0.0163 & -0.0386 & $0.0328 * *$ & 0.0337 \\
\hline & $(0.0950)$ & $(0.0550)$ & $(0.0640)$ & $(0.0260)$ & $(0.0500)$ & $(0.1790)$ & $(0.0450)$ & $(0.0890)$ & $(0.1810)$ & $(0.1000)$ \\
\hline \multirow[t]{2}{*}{ Durable Goods and Mortgage } & $-0.0922^{* * *}$ & $0.1072^{* * *}$ & $-0.0789^{* * *}$ & 0.0342 & -0.0716 & -0.0502 & $-0.1049^{* * *}$ & 0.0029 & $0.1197^{* * *}$ & $0.1392^{* * *}$ \\
\hline & $(0.4380)$ & $(0.4590)$ & $(0.4250)$ & $(0.0170)$ & $(0.0510)$ & $(0.0170)$ & $(0.5060)$ & $(0.0000)$ & $(0.6620)$ & $(0.4720)$ \\
\hline
\end{tabular}


Table 7. Cont.

\begin{tabular}{|c|c|c|c|c|c|c|c|c|c|c|}
\hline Traditional CCAPM & $\begin{array}{c}0.0431 \\
(0.1050)\end{array}$ & $\begin{array}{c}0.1266^{* *} \\
(0.1920)\end{array}$ & $\begin{array}{c}-0.0736^{* *} \\
(0.1710)\end{array}$ & $\begin{array}{l}-0.0106 \\
(0.0030)\end{array}$ & $\begin{array}{c}0.0207 \\
(0.0320)\end{array}$ & $\begin{array}{c}-0.0656^{* *} \\
(0.2030)\end{array}$ & $\begin{array}{c}-0.0106 \\
(0.0020)\end{array}$ & $\begin{array}{c}-0.0234 \\
(0.0160)\end{array}$ & $\begin{array}{c}0.0344 \\
(0.0530)\end{array}$ & $\begin{array}{c}0.1177^{* *} \\
(0.2530)\end{array}$ \\
\hline \multirow[t]{2}{*}{ Durable Goods } & 0.0099 & 0.0595 & $-0.1199 * *$ & $-0.0919 *$ & -0.0179 & $-0.1282^{* * *}$ & -0.1049 * & 0.0584 & -0.0316 & 0.0842 \\
\hline & $(0.0030)$ & $(0.0250)$ & $(0.2650)$ & $(0.1390)$ & $(0.0140)$ & $(0.4540)$ & $(0.1270)$ & $(0.0580)$ & $(0.0260)$ & $(0.0760)$ \\
\hline \multirow[t]{2}{*}{ Durable Goods and Real Estate } & $0.0457^{* *}$ & 0.0814 * & $-0.0480 *$ & 0.0063 & 0.0246 & -0.0313 & -0.0053 & -0.0252 & 0.0272 & 0.0606 * \\
\hline & $(0.2270)$ & $(0.1520)$ & $(0.1400)$ & $(0.0020)$ & $(0.0860)$ & $(0.0890)$ & $(0.0010)$ & $(0.0360)$ & $(0.0640)$ & $(0.1290)$ \\
\hline \multirow[t]{2}{*}{ Durable Goods and Mortgage } & 0.007 & 0.0443 & $-0.1369^{* *}$ & $-0.1110^{* *}$ & -0.0247 & $-0.1418^{* * *}$ & $-0.1232^{* *}$ & 0.0698 & -0.0384 & 0.0698 \\
\hline & $(0.0010)$ & $(0.0120)$ & $(0.3130)$ & $(0.1840)$ & $(0.0240)$ & $(0.5030)$ & $(0.1580)$ & $(0.0750)$ & $(0.0350)$ & $(0.0470)$ \\
\hline Traditional CCAPM & $0.0733^{* * *}$ & $0.1101^{* * *}$ & $0.0805^{* * *}$ & $-0.0966^{* *}$ & $0.1120 * *$ & $0.0914^{* *}$ & -0.0457 & $0.1298 * *$ & 0.0531 & $-0.0896^{* *}$ \\
\hline \multirow[t]{2}{*}{ Durable Goods } & $0.1016^{* * *}$ & $0.1740^{* * *}$ & $0.1037^{* * *}$ & -0.064 & $0.1552 * *$ & $0.1526^{* * *}$ & $-0.1697^{* *}$ & $0.2153 * * *$ & 0.0756 & -0.0495 \\
\hline & $(0.5560)$ & $(0.6240)$ & $(0.4290)$ & $(0.0550)$ & $(0.3250)$ & $(0.5270)$ & $(0.2030)$ & $(0.5110)$ & $(0.0550)$ & $(0.0310)$ \\
\hline \multirow[t]{2}{*}{ Durable Goods and Real Estate } & $0.0553^{* * *}$ & $0.0763^{* * *}$ & $0.0766^{* * *}$ & $-0.0667^{* *}$ & $0.0734^{* *}$ & $0.0502 * *$ & -0.022 & $0.0804^{* *}$ & 0.0367 & $-0.0766^{* *}$ \\
\hline & $(0.5420)$ & $(0.3950)$ & $(0.7720)$ & $(0.1970)$ & $(0.2390)$ & $(0.1880)$ & $(0.0110)$ & $(0.2350)$ & $(0.0430)$ & $(0.2440)$ \\
\hline \multirow[t]{2}{*}{ Durable Goods and Mortgage } & $0.1113^{* * *}$ & $0.1839 * * *$ & $0.1165^{* * *}$ & -0.0726 & $0.1848^{* * *}$ & $0.1645^{* * *}$ & $-0.1948^{* *}$ & $0.2361 * * *$ & 0.0672 & -0.0473 \\
\hline & $(0.6040)$ & $(0.6320)$ & $(0.4910)$ & $(0.0640)$ & $(0.4160)$ & $(0.5550)$ & $(0.2420)$ & $(0.5560)$ & $(0.0400)$ & $(0.0260)$ \\
\hline \multirow[t]{2}{*}{ Traditional CCAPM } & $-0.1683^{* *}$ & $-0.1335^{* * *}$ & 0.015 & -0.0027 & -0.0276 & $0.0919 *$ & -0.043 & $-0.0721^{* *}$ & $0.0260 *$ & $0.0443 * *$ \\
\hline & $(0.3080)$ & $(0.8050)$ & $(0.0180)$ & $(0.0010)$ & $(0.0900)$ & $(0.1280)$ & $(0.0480)$ & $(0.1860)$ & $(0.1200)$ & $(0.2820)$ \\
\hline Durable Goods & $-0.1975^{* *}$ & $-0.1406^{* * *}$ & $0.0691^{* *}$ & 0.0284 & $-0.0679^{* *}$ & $0.1634^{* *}$ & $-0.0863 *$ & $-0.0889 * *$ & 0.0105 & $0.0745^{* * *}$ \\
\hline \multirow[t]{2}{*}{ Durable Goods and Real Estate } & $-0.1141^{* *}$ & $-0.0827^{* * *}$ & 0.0068 & -0.0234 & -0.0132 & 0.0603 & -0.043 & $-0.0551^{* *}$ & $0.0327^{* *}$ & $0.0291^{* *}$ \\
\hline & $(0.2720)$ & $(0.5950)$ & $(0.0070)$ & $(0.0760)$ & $(0.0390)$ & $(0.1060)$ & $(0.0930)$ & $(0.2090)$ & $(0.3660)$ & $(0.2350)$ \\
\hline \multirow[t]{2}{*}{ Durable Goods and Mortgage } & $-0.2379^{* *}$ & $-0.1469^{* * *}$ & $0.0783^{* *}$ & 0.0319 & $-0.0770^{* *}$ & $0.1677^{* *}$ & -0.0941 * & -0.0800 * & 0.0116 & $0.0844^{* * *}$ \\
\hline & $(0.3250)$ & $(0.5160)$ & $(0.2580)$ & $(0.0390)$ & $(0.3700)$ & $(0.2250)$ & $(0.1220)$ & $(0.1210)$ & $(0.0130)$ & $(0.5420)$ \\
\hline \multirow[t]{2}{*}{ Traditional CCAPM } & 0.0493 & $0.0722 * * *$ & $0.0591^{* *}$ & -0.063 & -0.0091 & $0.0572 * *$ & -0.0488 & 0.018 & 0.0027 & $-0.0851^{* * *}$ \\
\hline & $(0.0640)$ & $(0.3890)$ & $(0.2860)$ & $(0.0530)$ & $(0.0030)$ & $(0.3290)$ & $(0.0380)$ & $(0.0120)$ & $(0.0010)$ & $(0.4800)$ \\
\hline \multirow[t]{2}{*}{ Durable Goods } & $0.1228^{* *}$ & $0.1226^{* * *}$ & $0.0970^{* * *}$ & -0.032 & -0.0689 & $0.1054^{* * *}$ & -0.0885 & 0.0665 & 0.0406 & $-0.0938^{* *}$ \\
\hline & $(0.2310)$ & $(0.6570)$ & $(0.4510)$ & $(0.0080)$ & $(0.1060)$ & $(0.6530)$ & $(0.0730)$ & $(0.0970)$ & $(0.0890)$ & $(0.3410)$ \\
\hline \multirow[t]{2}{*}{ Durable Goods and Real Estate } & 0.0157 & $0.0546^{* * *}$ & $0.0484^{* *}$ & -0.0546 & -0.0048 & $0.0425^{* *}$ & -0.0043 & 0.0376 & 0.0092 & $-0.0669^{* * *}$ \\
\hline & $(0.0120)$ & $(0.4290)$ & $(0.3700)$ & $(0.0770)$ & $(0.0020)$ & $(0.3490)$ & $(0.0010)$ & $(0.1020)$ & $(0.0150)$ & $(0.5720)$ \\
\hline \multirow[t]{2}{*}{ Durable Goods and Mortgage } & 0.1320 ** & $0.1324^{* * *}$ & $0.1049^{* * *}$ & -0.0305 & $-0.0864 *$ & $0.1159^{* * *}$ & -0.0637 & 0.0825 * & $0.0528 *$ & $-0.0948^{* *}$ \\
\hline & $(0.2420)$ & $(0.6930)$ & $(0.4770)$ & $(0.0070)$ & $(0.1510)$ & $(0.7140)$ & $(0.0340)$ & $(0.1350)$ & $(0.1360)$ & $(0.3150)$ \\
\hline
\end{tabular}


Table 7. Cont.

\begin{tabular}{|c|c|c|c|c|c|c|c|c|c|c|}
\hline Traditional CCAPM & $\begin{array}{c}-0.0654 \text { * } \\
(0.1490)\end{array}$ & $\begin{array}{c}-0.0141 \\
(0.0150)\end{array}$ & $\begin{array}{c}0.0025 \\
(0.0000)\end{array}$ & $\begin{array}{c}0.1053 \text { ** } \\
(0.3170)\end{array}$ & $\begin{array}{l}0.0853 \text { * } \\
(0.1230)\end{array}$ & $\begin{array}{c}-0.0076 \\
(0.0010)\end{array}$ & $\begin{array}{c}0.1169 * * \\
(0.3660)\end{array}$ & $\begin{array}{c}-0.0216 \\
(0.0080)\end{array}$ & $\begin{array}{c}0.0860 * * \\
(0.2700)\end{array}$ & $\begin{array}{c}0.1714^{* *} \\
(0.2360)\end{array}$ \\
\hline \multirow[t]{2}{*}{ Durable Goods } & -0.059 & $-0.0663^{* *}$ & -0.0433 & $0.1052 * *$ & 0.025 & 0.0188 & $0.1920^{* * *}$ & $-0.1353^{* *}$ & $0.1432^{* * *}$ & 0.0994 \\
\hline & $(0.0710)$ & $(0.1920)$ & $(0.0790)$ & $(0.1850)$ & $(0.0060)$ & $(0.0030)$ & $(0.5770)$ & $(0.1930)$ & $(0.4370)$ & $(0.0460)$ \\
\hline \multirow[t]{2}{*}{ Durable Goods and Real Estate } & $-0.0508^{* *}$ & 0.0028 & 0.0046 & $0.0673 * *$ & $0.0721 * *$ & -0.0025 & $0.0769 * *$ & -0.0179 & $0.0573 * *$ & $0.0983 *$ \\
\hline & $(0.1730)$ & $(0.0010)$ & $(0.0030)$ & $(0.2480)$ & $(0.1690)$ & $(0.0000)$ & $(0.3040)$ & $(0.0110)$ & $(0.2300)$ & $(0.1490)$ \\
\hline \multirow[t]{2}{*}{ Durable Goods and Mortgage } & -0.0781 & $-0.0682^{* *}$ & -0.051 & $0.0993 *$ & 0.0383 & 0.0221 & $0.2079^{* * *}$ & $-0.1522 * *$ & $0.1613^{* * *}$ & 0.1029 \\
\hline & $(0.1130)$ & $(0.1840)$ & $(0.0990)$ & $(0.1490)$ & $(0.0130)$ & $(0.0040)$ & $(0.6120)$ & $(0.2210)$ & $(0.5020)$ & $(0.0450)$ \\
\hline Traditional CCAPM & $0.0629 * * *$ & 0.0011 & $0.0874^{* *}$ & $-0.0909 * *$ & -0.0492 & -0.017 & 0.0264 & $-0.1043^{* *}$ & -0.0088 & $0.0777 *$ \\
\hline \multirow[t]{2}{*}{ Durable Goods } & $0.0545 * *$ & 0.0325 & 0.0538 & $-0.1236^{* *}$ & -0.0465 & -0.089 & 0.0334 & -0.065 & 0.0392 & $0.1027^{* *}$ \\
\hline & $(0.1990)$ & $(0.0230)$ & $(0.0470)$ & $(0.2910)$ & $(0.0320)$ & $(0.1020)$ & $(0.0130)$ & $(0.0380)$ & $(0.0670)$ & $(0.1580)$ \\
\hline \multirow[t]{2}{*}{ Durable Goods and Real Estate } & $0.0484^{* * *}$ & $-0.0399 *$ & $0.0634^{* *}$ & $-0.0799^{* * *}$ & $-0.0869^{* *}$ & -0.0145 & -0.0366 & $-0.1219^{* * *}$ & -0.0066 & 0.0155 \\
\hline & $(0.5170)$ & $(0.1150)$ & $(0.2150)$ & $(0.4010)$ & $(0.3670)$ & $(0.0090)$ & $(0.0530)$ & $(0.4440)$ & $(0.0060)$ & $(0.0120)$ \\
\hline \multirow[t]{2}{*}{ Durable Goods and Mortgage } & $0.0610^{* *}$ & 0.0248 & 0.0657 & $-0.1463^{* *}$ & -0.0594 & $-0.1178^{* *}$ & 0.019 & -0.071 & 0.0406 & 0.0876 \\
\hline & $(0.2250)$ & $(0.0120)$ & $(0.0630)$ & $(0.3700)$ & $(0.0470)$ & $(0.1620)$ & $(0.0040)$ & $(0.0410)$ & $(0.0650)$ & $(0.1040)$ \\
\hline \multirow[t]{2}{*}{ Traditional CCAPM } & $0.0618^{* *}$ & 0.0309 & -0.0286 & $0.0581 * * *$ & $-0.1010 * *$ & $-0.1415^{* * *}$ & 0.032 & -0.0102 & $-0.1797 * *$ & -0.0559 ** \\
\hline & $(0.2530)$ & $(0.0140)$ & $(0.0440)$ & $(0.4080)$ & $(0.3680)$ & $(0.5200)$ & $(0.0050)$ & $(0.0020)$ & $(0.3690)$ & $(0.1800)$ \\
\hline Durable Goods & $-0.0920^{* *}$ & $0.0662^{* *}$ & $-0.1119^{* *}$ & $-0.1966^{* * *}$ & 0.0356 & 0.0112 & $-0.2465^{* * *}$ & $-0.1079^{* * *}$ & $-0.0980^{* *}$ & $0.0948^{* *}$ \\
\hline \multirow[t]{2}{*}{ Durable Goods and Real Estate } & 0.0224 & 0.0119 & -0.0038 & $0.0540^{* * *}$ & $-0.0867^{* * *}$ & $-0.0942^{* * *}$ & 0.0822 & -0.0219 & $-0.1230^{* *}$ & $-0.0330 *$ \\
\hline & $(0.0640)$ & $(0.0040)$ & $(0.0010)$ & $(0.6760)$ & $(0.5210)$ & $(0.4430)$ & $(0.0680)$ & $(0.0190)$ & $(0.3330)$ & $(0.1210)$ \\
\hline \multirow[t]{2}{*}{ Durable Goods and Mortgage } & $0.1099 * * *$ & 0.0092 & $-0.0971^{* *}$ & $0.0728^{* *}$ & $-0.1191 * *$ & $-0.2111^{* * *}$ & 0.0364 & 0.0301 & $-0.2591^{* * *}$ & $-0.1225^{* * *}$ \\
\hline & $(0.4230)$ & $(0.0010)$ & $(0.2660)$ & $(0.3380)$ & $(0.2710)$ & $(0.6110)$ & $(0.0040)$ & $(0.0100)$ & $(0.4060)$ & $(0.4560)$ \\
\hline \multirow[t]{2}{*}{ Traditional CCAPM } & $0.0719 * *$ & 0.0418 & -0.0113 & -0.0359 & -0.0068 & -0.0236 & -0.02 & 0.0919 * & 0.0933 * & -0.0095 \\
\hline & $(0.3650)$ & $(0.0690)$ & $(0.0050)$ & $(0.0340)$ & $(0.0010)$ & $(0.0120)$ & $(0.0060)$ & $(0.1400)$ & $(0.1520)$ & $(0.0010)$ \\
\hline \multirow[t]{2}{*}{ Durable Goods } & $0.1146^{* *}$ & $0.0682 * *$ & 0.031 & 0.0435 & -0.057 & 0.028 & 0.0151 & 0.0374 & $0.1433 * *$ & $0.1884^{* *}$ \\
\hline & $(0.1760)$ & $(0.1920)$ & $(0.0220)$ & $(0.0410)$ & $(0.0510)$ & $(0.0110)$ & $(0.0030)$ & $(0.0120)$ & $(0.1990)$ & $(0.3620)$ \\
\hline \multirow[t]{2}{*}{ Durable Goods and Real Estate } & $0.0603^{* *}$ & $0.0685^{* * *}$ & $0.0474^{* *}$ & 0.0067 & -0.012 & -0.0265 & -0.008 & $-0.0727 *$ & 0.0399 & 0.0346 \\
\hline & $(0.1610)$ & $(0.6360)$ & $(0.1700)$ & $(0.0030)$ & $(0.0070)$ & $(0.0330)$ & $(0.0030)$ & $(0.1450)$ & $(0.0510)$ & $(0.0400)$ \\
\hline \multirow[t]{2}{*}{ Durable Goods and Mortgage } & $0.1145^{* *}$ & $0.0824^{* *}$ & 0.0331 & 0.0571 & -0.0575 & 0.0252 & 0.0175 & 0.0315 & $0.1342 * *$ & $0.1962 * *$ \\
\hline & $(0.1590)$ & $(0.2530)$ & $(0.0230)$ & $(0.0650)$ & $(0.0470)$ & $(0.0080)$ & $(0.0030)$ & $(0.0080)$ & $(0.1580)$ & $(0.3550)$ \\
\hline
\end{tabular}


Table 7. Cont.

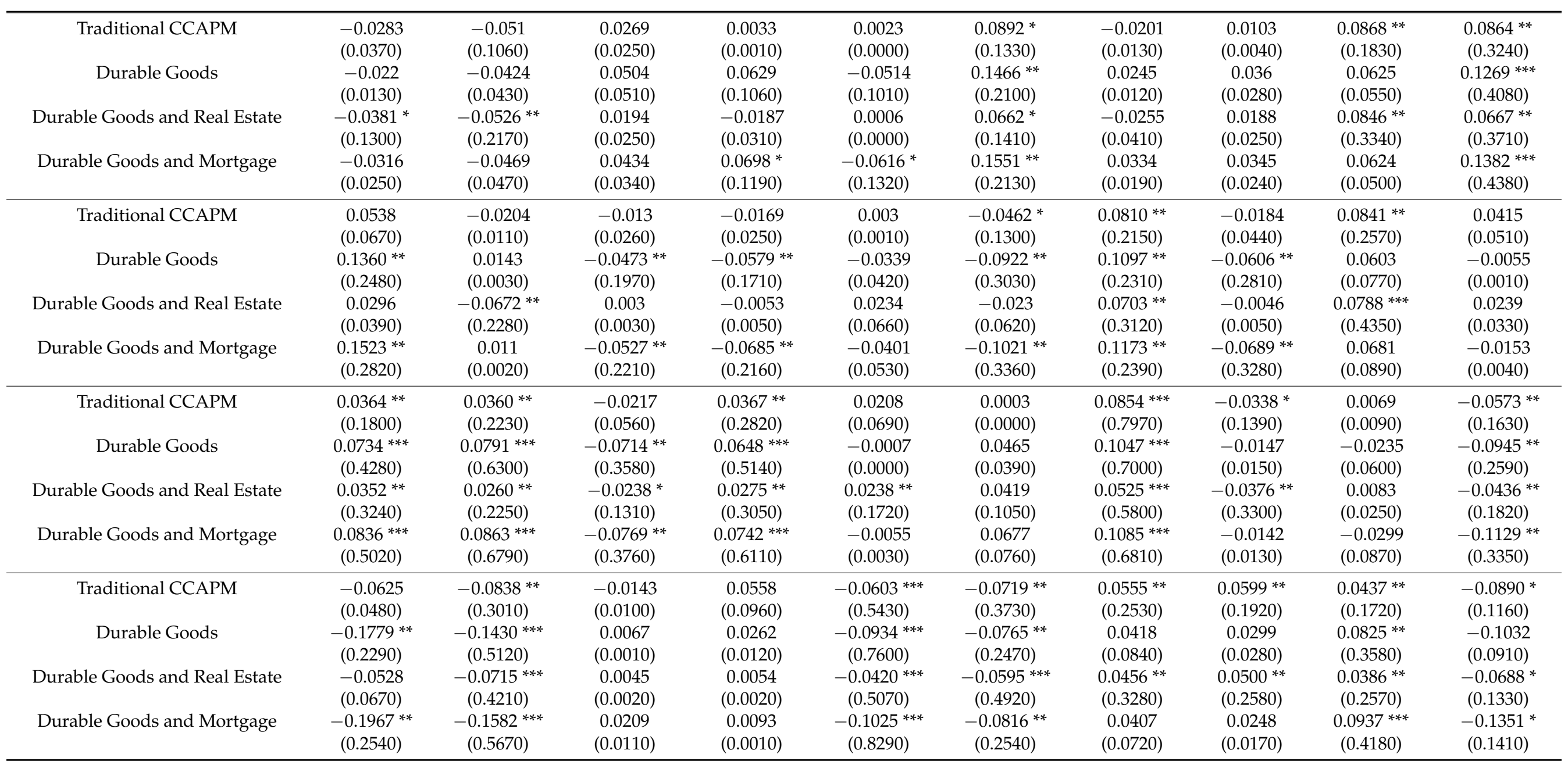


Table 7. Cont.

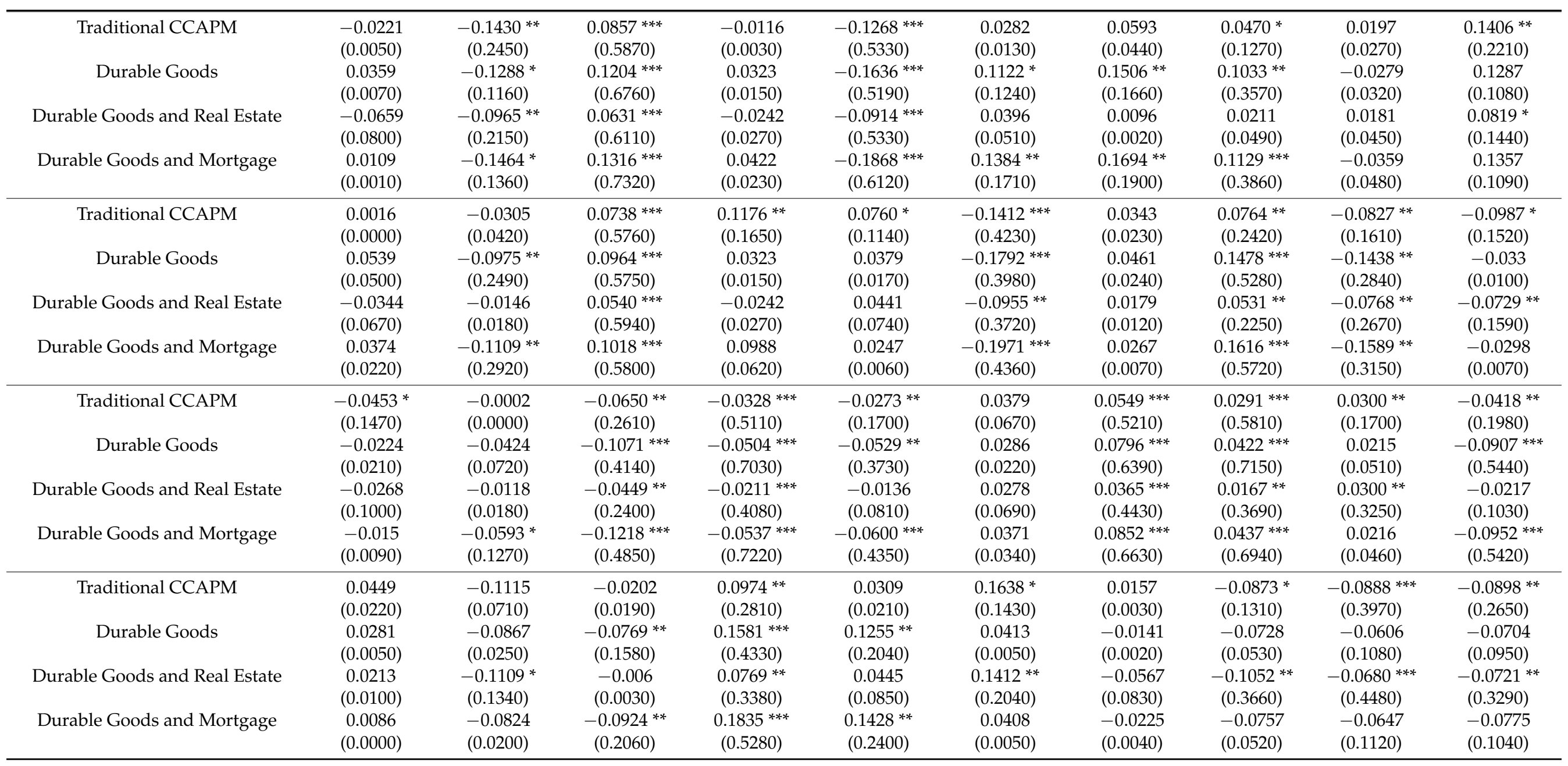


Table 7. Cont.

\begin{tabular}{|c|c|c|c|c|c|c|c|c|c|c|}
\hline Traditional CCAPM & $\begin{array}{c}-0.0787^{* *} \\
(0.2390)\end{array}$ & $\begin{array}{c}0.0068 \\
(0.0010)\end{array}$ & $\begin{array}{c}0.0862 \\
(0.0540)\end{array}$ & $\begin{array}{c}0.0942 \text { ** } \\
(0.2890)\end{array}$ & $\begin{array}{c}0.1850 * * \\
(0.3520)\end{array}$ & $\begin{array}{c}0.0319 \\
(0.0140)\end{array}$ & $\begin{array}{c}-0.0814^{* *} \\
(0.1840)\end{array}$ & $\begin{array}{c}0.0201 \\
(0.0040)\end{array}$ & $\begin{array}{c}0.2079 * * \\
(0.3150)\end{array}$ & $\begin{array}{c}0.0662 \\
(0.0980)\end{array}$ \\
\hline \multirow[t]{2}{*}{ Durable Goods } & $-0.1188^{* *}$ & 0.0071 & 0.1465 & $0.1092 * *$ & $0.1586 *$ & -0.0263 & $-0.1534^{* * *}$ & 0.0209 & $0.1992 * *$ & $0.1472 * *$ \\
\hline & $(0.3180)$ & $(0.0010)$ & $(0.0910)$ & $(0.2270)$ & $(0.1510)$ & $(0.0050)$ & $(0.3830)$ & $(0.0020)$ & $(0.1690)$ & $(0.2840)$ \\
\hline \multirow[t]{2}{*}{ Durable Goods and Real Estate } & -0.0219 & 0.0052 & $0.0945 *$ & $0.0530 * *$ & $0.1019 * *$ & 0.0645 & $-0.0562^{* *}$ & 0.0531 & $0.1199 * *$ & 0.0171 \\
\hline & $(0.0360)$ & $(0.0010)$ & $(0.1240)$ & $(0.1760)$ & $(0.2050)$ & $(0.1080)$ & $(0.1690)$ & $(0.0500)$ & $(0.2020)$ & $(0.0130)$ \\
\hline \multirow[t]{2}{*}{ Durable Goods and Mortgage } & $-0.1081^{* *}$ & -0.0003 & 0.1754 * & $0.1160 * *$ & $0.1678 *$ & -0.0134 & $-0.1757^{* * *}$ & 0.0404 & $0.2078 * *$ & $0.1626^{* *}$ \\
\hline & $(0.2380)$ & $(0.0000)$ & $(0.1180)$ & $(0.2310)$ & $(0.1530)$ & $(0.0010)$ & $(0.4540)$ & $(0.0080)$ & $(0.1670)$ & $(0.3140)$ \\
\hline Traditional CCAPM & $-0.1081^{* *}$ & 0.0305 & $-0.1116^{* * *}$ & -0.0464 & 0.0523 & $-0.1098 * *$ & $-0.0441^{* * *}$ & $-0.0318^{* *}$ & $-0.0899 * *$ & 0.0151 \\
\hline \multirow[t]{2}{*}{ Durable Goods } & $-0.1598^{* * *}$ & -0.0464 & $0.1546^{* * *}$ & $-0.1864^{* * *}$ & $-0.0384^{* *}$ & $-0.0657^{* * *}$ & $-0.0865^{* *}$ & -0.0231 & 0.0215 & $-0.0907^{* * *}$ \\
\hline & $(0.4830)$ & $(0.0390)$ & $(0.4240)$ & $(0.4900)$ & $(0.2670)$ & $(0.4820)$ & $(0.1650)$ & $(0.0400)$ & $(0.0710)$ & $(0.5440)$ \\
\hline \multirow[t]{2}{*}{ Durable Goods and Real Estate } & $-0.0868^{* * *}$ & 0.0056 & $-0.0999^{* * *}$ & -0.056 & 0.0276 & $-0.0512 *$ & $-0.0341^{* * *}$ & $-0.0221 * *$ & $-0.0869^{* * *}$ & 0.016 \\
\hline & $(0.4440)$ & $(0.0030)$ & $(0.6220)$ & $(0.1100)$ & $(0.0440)$ & $(0.1220)$ & $(0.6940)$ & $(0.1790)$ & $(0.5470)$ & $(0.0640)$ \\
\hline \multirow[t]{2}{*}{ Durable Goods and Mortgage } & $-0.0984^{*}$ & $0.1024^{* *}$ & $-0.1689^{* * *}$ & -0.002 & $0.1634^{* * *}$ & $-0.1901^{* * *}$ & $-0.0421^{* *}$ & $-0.0689^{* * *}$ & $-0.0932^{* *}$ & -0.0248 \\
\hline & $(0.1570)$ & $(0.3010)$ & $(0.4880)$ & $(0.0000)$ & $(0.4290)$ & $(0.4620)$ & $(0.2910)$ & $(0.4790)$ & $(0.1730)$ & $(0.0420)$ \\
\hline \multirow[t]{2}{*}{ Traditional CCAPM } & $-0.1612^{* * *}$ & 0.0441 & $0.0828^{* *}$ & 0.0508 & 0.0801 & $0.0689 * *$ & $0.0289 * *$ & $-0.0975^{* *}$ & 0.0021 & $0.0377^{* *}$ \\
\hline & $(0.4240)$ & $(0.0730)$ & $(0.2380)$ & $(0.0700)$ & $(0.0570)$ & $(0.1910)$ & $(0.2210)$ & $(0.1650)$ & $(0.0000)$ & $(0.2820)$ \\
\hline Durable Goods & $-0.2252^{* * *}$ & $0.0944^{* *}$ & 0.0733 & 0.0292 & $0.1903^{* *}$ & $0.1327^{* * *}$ & 0.0052 & -0.0945 & -0.0919 & $0.0722 * * *$ \\
\hline \multirow[t]{2}{*}{ Durable Goods and Real Estate } & $-0.1080^{* *}$ & 0.026 & $0.0850^{* * *}$ & $0.0605^{* *}$ & 0.0733 & $0.0433 *$ & $0.0293^{* * *}$ & -0.0151 & -0.0501 & $0.0260^{* *}$ \\
\hline & $(0.3660)$ & $(0.0490)$ & $(0.4830)$ & $(0.1900)$ & $(0.0920)$ & $(0.1450)$ & $(0.4390)$ & $(0.0060)$ & $(0.0840)$ & $(0.2580)$ \\
\hline \multirow[t]{2}{*}{ Durable Goods and Mortgage } & $-0.2382^{* * *}$ & $0.1115^{* *}$ & 0.0809 * & 0.0478 & $0.2166^{* *}$ & $0.1453^{* * *}$ & 0.0221 & -0.1106 & -0.071 & $0.0784^{* * *}$ \\
\hline & $(0.4900)$ & $(0.2490)$ & $(0.1200)$ & $(0.0330)$ & $(0.2210)$ & $(0.4490)$ & $(0.0680)$ & $(0.0890)$ & $(0.0460)$ & $(0.6450)$ \\
\hline \multirow[t]{2}{*}{ Traditional CCAPM } & 0.0592 & -0.0087 & $-0.0639 * *$ & $-0.0779 * *$ & $0.0893^{* * *}$ & 0.0337 & $0.0798 * *$ & $0.0328 * *$ & 0.0679 & $0.1258 * *$ \\
\hline & $(0.0920)$ & $(0.0020)$ & $(0.1750)$ & $(0.2400)$ & $(0.5780)$ & $(0.0230)$ & $(0.2390)$ & $(0.2010)$ & $(0.0850)$ & $(0.2420)$ \\
\hline \multirow[t]{2}{*}{ Durable Goods } & $0.1391^{* *}$ & 0.0611 & -0.0408 & -0.0676 & $0.1173^{* * *}$ & 0.0961 & $0.1487^{* * *}$ & 0.0135 & $0.1372 * *$ & $0.2433^{* * *}$ \\
\hline & $(0.2950)$ & $(0.0690)$ & $(0.0420)$ & $(0.1060)$ & $(0.5830)$ & $(0.1070)$ & $(0.4850)$ & $(0.0200)$ & $(0.2030)$ & $(0.5280)$ \\
\hline \multirow[t]{2}{*}{ Durable Goods and Real Estate } & 0.0554 * & -0.0095 & $-0.0669^{* *}$ & $-0.0817^{* * *}$ & $0.0699 * * *$ & 0.0307 & $0.0471^{* *}$ & $0.0315^{* *}$ & 0.0173 & 0.0615 \\
\hline & $(0.1540)$ & $(0.0050)$ & $(0.3690)$ & $(0.5080)$ & $(0.6810)$ & $(0.0360)$ & $(0.1600)$ & $(0.3560)$ & $(0.0110)$ & $(0.1110)$ \\
\hline \multirow[t]{2}{*}{ Durable Goods and Mortgage } & $0.1659 * *$ & 0.0775 & -0.0434 & -0.0694 & $0.1277^{* * *}$ & 0.086 & $0.1625^{* * *}$ & 0.0134 & $0.1553 * *$ & $0.2513^{* * *}$ \\
\hline & $(0.3810)$ & $(0.1000)$ & $(0.0430)$ & $(0.1010)$ & $(0.6250)$ & $(0.0780)$ & $(0.5240)$ & $(0.0180)$ & $(0.2350)$ & $(0.5100)$ \\
\hline
\end{tabular}


Table 7. Cont.

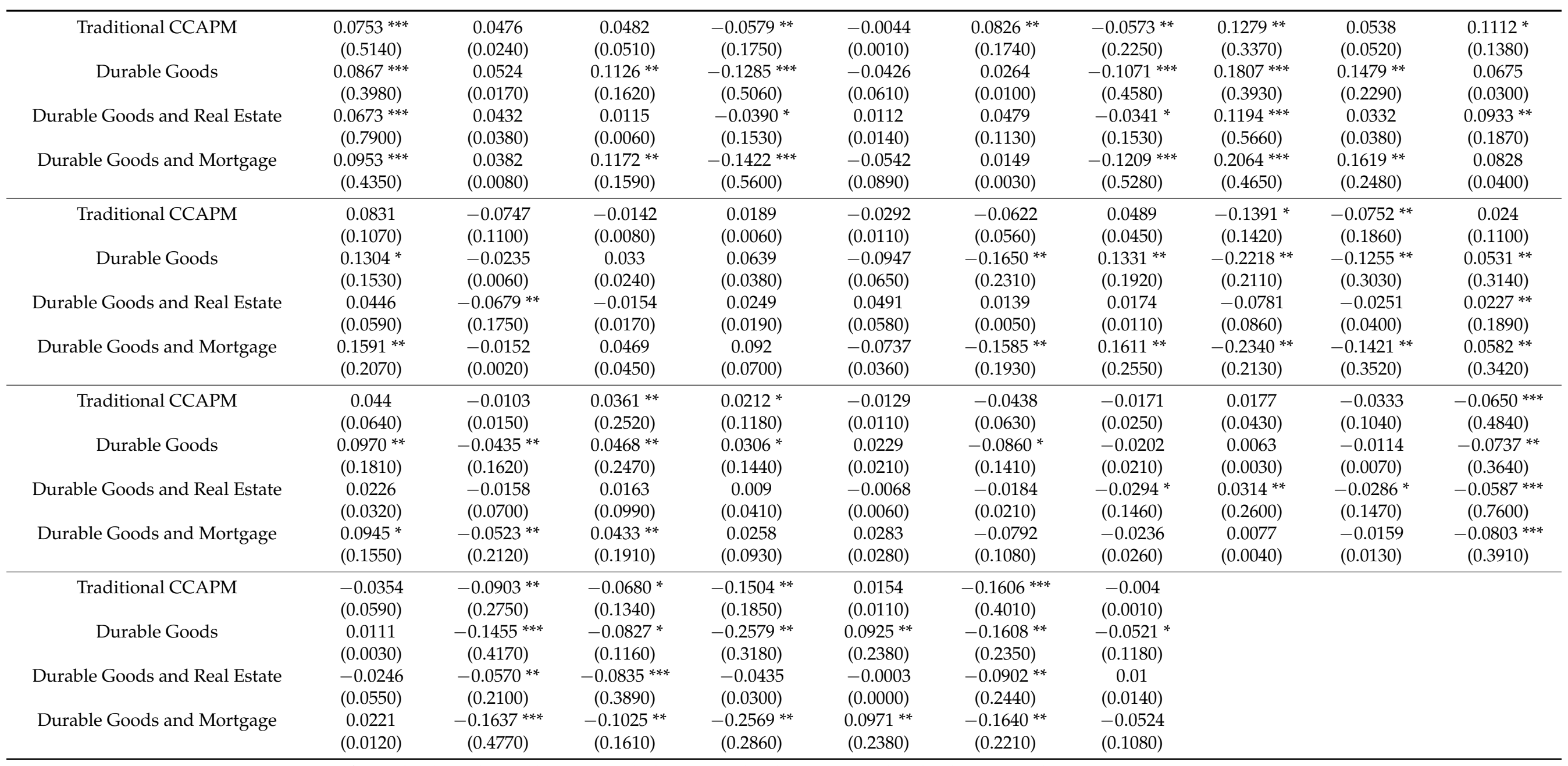

Note: significance levels are denoted by ${ }^{*}{ }^{* *}, * * *$, which correspond to the $10 \%, 5 \%$, and $1 \%$ levels, respectively. 
Table 8. Cross-sectional regression results on adjusted R-squares under the conditions of different factors based on the portfolios formed on the size and short-term reversal.

\begin{tabular}{|c|c|c|c|c|c|c|c|c|c|c|}
\hline Traditional CCAPM & $\begin{array}{c}0.0726^{* *} \\
(0.2810)\end{array}$ & $\begin{array}{l}0.0721 * \\
(0.1270)\end{array}$ & $\begin{array}{c}0.0484 \\
(0.0430)\end{array}$ & $\begin{array}{c}0.0586^{* *} \\
(0.1900)\end{array}$ & $\begin{array}{l}-0.0024 \\
(0.0010)\end{array}$ & $\begin{array}{c}0.0457 \\
(0.0220)\end{array}$ & $\begin{array}{c}0.016 \\
(0.0110)\end{array}$ & $\begin{array}{c}0.0302 \\
(0.0750)\end{array}$ & $\begin{array}{c}0.0494^{* *} \\
(0.1840)\end{array}$ & $\begin{array}{c}0.0674^{* *} \\
(0.2060)\end{array}$ \\
\hline \multirow[t]{2}{*}{ Durable Goods } & $0.0097 * *$ & $0.0148^{* *}$ & $0.0139 * *$ & 0.0048 & $-0.0045^{*}$ & 0.0091 & $0.0118^{* *}$ & $0.0096^{* * *}$ & 0.001 & 0.0024 \\
\hline & $(0.3080)$ & $(0.3300)$ & $(0.2180)$ & $(0.0800)$ & $(0.1160)$ & $(0.0530)$ & $(0.3560)$ & $(0.4620)$ & $(0.0050)$ & $(0.0160)$ \\
\hline \multirow[t]{2}{*}{ Durable Goods and Real Estate } & $0.0663^{* * *}$ & $0.0927^{* *}$ & $0.0620^{*}$ & $0.0637^{* * *}$ & 0.0113 & $0.0969^{* *}$ & 0.0291 & 0.0086 & $0.0365^{* *}$ & 0.0225 \\
\hline & $(0.4110)$ & $(0.3710)$ & $(0.1240)$ & $(0.3950)$ & $(0.0210)$ & $(0.1730)$ & $(0.0620)$ & $(0.0110)$ & $(0.1760)$ & $(0.0400)$ \\
\hline \multirow[t]{2}{*}{ Durable Goods and Mortgage } & $0.0898^{* *}$ & $0.1469^{* *}$ & 0.0935 & 0.0456 & $-0.0662 * *$ & 0.122 & $0.1263 * * *$ & $0.0983^{* * *}$ & -0.0083 & 0.0166 \\
\hline & $(0.2720)$ & $(0.3350)$ & $(0.1020)$ & $(0.0730)$ & $(0.2600)$ & $(0.0990)$ & $(0.4210)$ & $(0.5070)$ & $(0.0030)$ & $(0.0080)$ \\
\hline Traditional CCAPM & $-0.0644 *$ & 0.0039 & $0.0283^{* *}$ & 0.0014 & 0.0388 * & 0.0074 & -0.0007 & 0.0653 * & $-0.0646^{*}$ & 0.045 \\
\hline \multirow[t]{2}{*}{ Durable Goods } & 0 & $0.0066^{* * *}$ & -0.0012 & -0.0043 & -0.0026 & -0.001 & -0.0034 & $0.0088^{*}$ & 0.005 & 0.0003 \\
\hline & $(0.0000)$ & $(0.4690)$ & $(0.0230)$ & $(0.0550)$ & $(0.0370)$ & $(0.0040)$ & $(0.0970)$ & $(0.1470)$ & $(0.0470)$ & $(0.0000)$ \\
\hline \multirow[t]{2}{*}{ Durable Goods and Real Estate } & -0.0419 & -0.0085 & $0.0216^{* *}$ & 0.0263 & $0.0352 * *$ & $0.0402 * *$ & 0.01 & 0.0387 & 0.0049 & 0.0204 \\
\hline & $(0.1100)$ & $(0.0220)$ & $(0.2140)$ & $(0.0580)$ & $(0.1950)$ & $(0.1570)$ & $(0.0240)$ & $(0.0810)$ & $(0.0010)$ & $(0.0320)$ \\
\hline \multirow[t]{2}{*}{ Durable Goods and Mortgage } & 0.0088 & $0.0752 * * *$ & $-0.0262 *$ & $-0.0657^{*}$ & -0.0475 * & -0.0362 & $-0.0483^{* *}$ & 0.0859 * & 0.049 & -0.0037 \\
\hline & $(0.0020)$ & $(0.6210)$ & $(0.1140)$ & $(0.1310)$ & $(0.1280)$ & $(0.0460)$ & $(0.1990)$ & $(0.1450)$ & $(0.0470)$ & $(0.0000)$ \\
\hline \multirow[t]{2}{*}{ Traditional CCAPM } & 0.0055 & $0.1051^{* *}$ & 0.0426 & 0.0368 & 0.0208 & -0.0078 & $0.0703^{* *}$ & -0.0023 & -0.0092 & $0.0527^{* *}$ \\
\hline & $(0.0010)$ & $(0.2870)$ & $(0.0370)$ & $(0.0260)$ & $(0.0520)$ & $(0.0020)$ & $(0.1990)$ & $(0.0010)$ & $(0.0150)$ & $(0.2200)$ \\
\hline Durable Goods & 0.0014 & $0.0105^{* *}$ & -0.002 & $0.0171^{* *}$ & -0.003 & $0.0130 * *$ & -0.0032 & $-0.0050 * *$ & $-0.0060^{* * *}$ & 0.0019 \\
\hline \multirow[t]{2}{*}{ Durable Goods and Real Estate } & 0.0193 & $0.0659 * *$ & 0.0487 & 0.0397 & 0.0183 & 0.0421 & 0.0067 & -0.0153 & -0.0149 & $0.0514^{* *}$ \\
\hline & $(0.0230)$ & $(0.1990)$ & $(0.0860)$ & $(0.0540)$ & $(0.0710)$ & $(0.1040)$ & $(0.0030)$ & $(0.0750)$ & $(0.0690)$ & $(0.3670)$ \\
\hline \multirow[t]{2}{*}{ Durable Goods and Mortgage } & -0.0029 & $0.0994^{* *}$ & -0.0671 & $0.1565^{* *}$ & $-0.0509 * *$ & $0.1319 * *$ & -0.0408 & $-0.0574^{* *}$ & $-0.0668^{* * *}$ & 0.0031 \\
\hline & $(0.0000)$ & $(0.1630)$ & $(0.0590)$ & $(0.3020)$ & $(0.1970)$ & $(0.3690)$ & $(0.0420)$ & $(0.3800)$ & $(0.4960)$ & $(0.0000)$ \\
\hline \multirow[t]{2}{*}{ Traditional CCAPM } & $0.0246^{*}$ & $0.0441^{* *}$ & 0.0018 & $0.0505^{* *}$ & $0.0857^{* * *}$ & 0.0431 & -0.0069 & -0.0199 & 0.0094 & $0.0473^{* * *}$ \\
\hline & $(0.1480)$ & $(0.2950)$ & $(0.0010)$ & $(0.1980)$ & $(0.3950)$ & $(0.0780)$ & $(0.0060)$ & $(0.0240)$ & $(0.0140)$ & $(0.4170)$ \\
\hline \multirow[t]{2}{*}{ Durable Goods } & -0.0026 & $0.0064^{* *}$ & $-0.0028^{* *}$ & $0.0078^{* *}$ & $0.0075^{* *}$ & $0.0085 * *$ & $-0.0061^{* *}$ & $0.0058^{*}$ & $0.0058^{* *}$ & $0.0043^{* *}$ \\
\hline & $(0.0980)$ & $(0.3770)$ & $(0.1960)$ & $(0.2860)$ & $(0.1840)$ & $(0.1870)$ & $(0.3100)$ & $(0.1250)$ & $(0.3290)$ & $(0.2100)$ \\
\hline \multirow[t]{2}{*}{ Durable Goods and Real Estate } & 0.014 & $0.0415^{* * *}$ & 0.0038 & 0.0135 & $0.0690^{* * *}$ & 0.0332 & 0.0025 & -0.0178 & 0.0137 & $0.0351^{* * *}$ \\
\hline & $(0.0840)$ & $(0.4580)$ & $(0.0100)$ & $(0.0250)$ & $(0.4510)$ & $(0.0810)$ & $(0.0010)$ & $(0.0330)$ & $(0.0540)$ & $(0.4050)$ \\
\hline \multirow[t]{2}{*}{ Durable Goods and Mortgage } & $-0.0368^{* *}$ & $0.0558^{* *}$ & $-0.0376^{* *}$ & $0.0832^{* *}$ & 0.0558 & 0.0745 * & $-0.0692^{* * *}$ & $0.0812 * *$ & $0.0681^{* * *}$ & $0.0408 * *$ \\
\hline & $(0.2100)$ & $(0.2980)$ & $(0.3590)$ & $(0.3400)$ & $(0.1060)$ & $(0.1480)$ & $(0.4110)$ & $(0.2520)$ & $(0.4750)$ & $(0.1970)$ \\
\hline
\end{tabular}


Table 8. Cont.

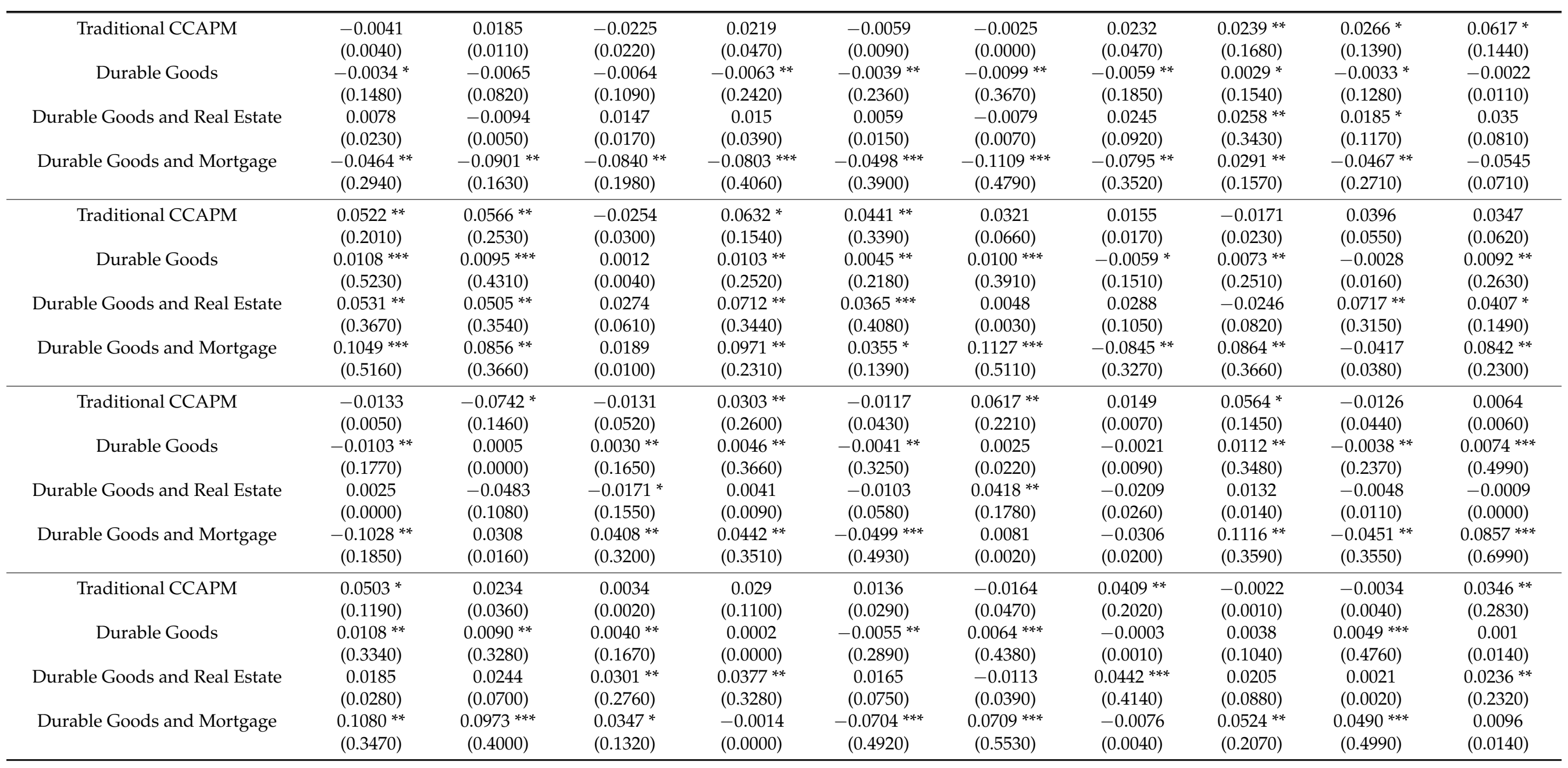


Table 8. Cont.

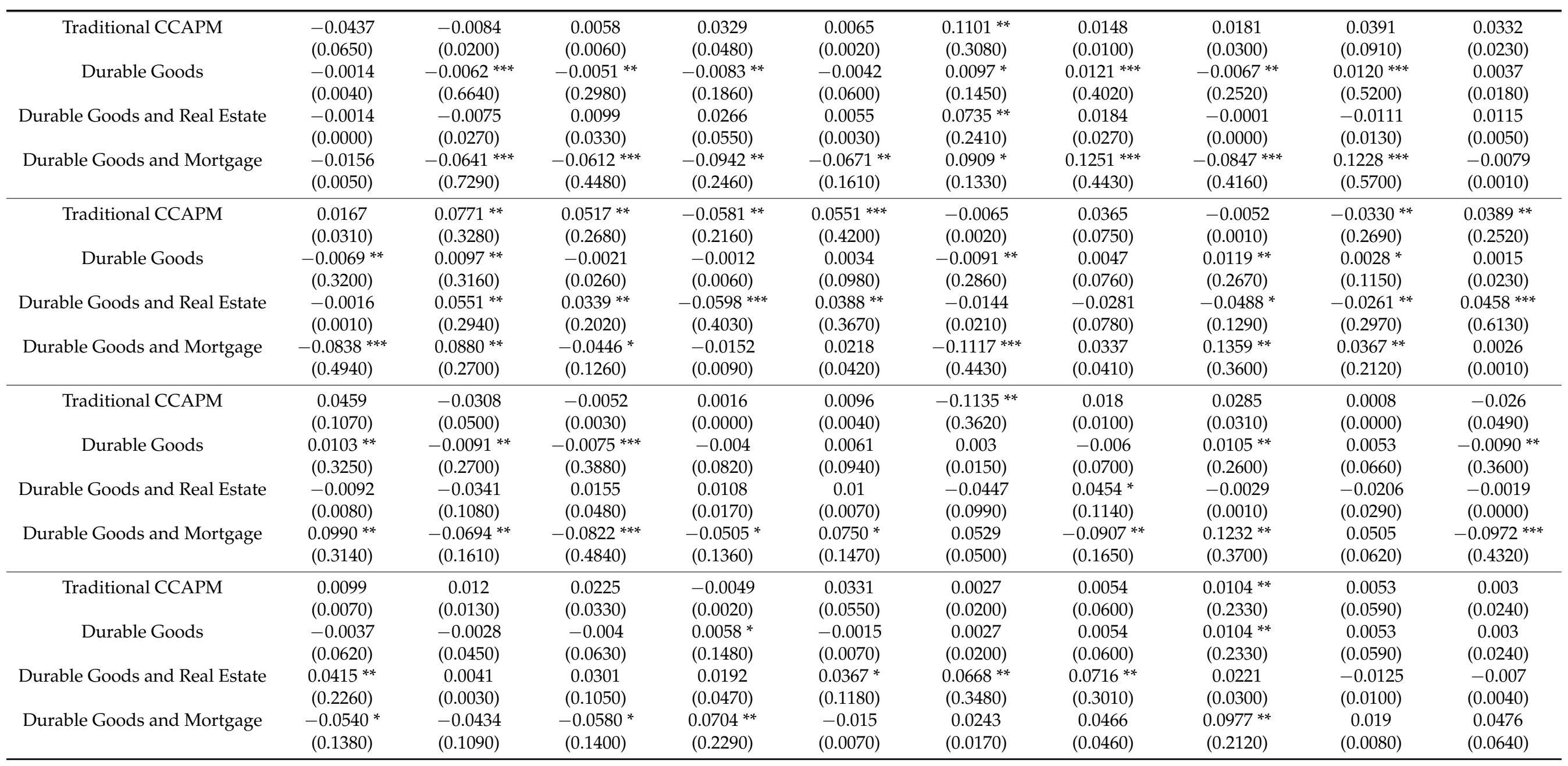


Table 8. Cont.

\begin{tabular}{|c|c|c|c|c|c|c|c|c|c|c|}
\hline Traditional CCAPM & $\begin{array}{c}0.004 \\
(0.0010)\end{array}$ & $\begin{array}{c}0.0018 \\
(0.0000)\end{array}$ & $\begin{array}{l}-0.0035 \\
(0.0010)\end{array}$ & $\begin{array}{c}0.0312 \\
(0.0680)\end{array}$ & $\begin{array}{c}0.0244 \\
(0.1080)\end{array}$ & $\begin{array}{c}0.0308 \\
(0.0980)\end{array}$ & $\begin{array}{l}-0.0032 \\
(0.0010)\end{array}$ & $\begin{array}{l}-0.0165 \\
(0.0130)\end{array}$ & $\begin{array}{l}-0.0079 \\
(0.0040)\end{array}$ & $\begin{array}{l}-0.0449 \\
(0.0770)\end{array}$ \\
\hline \multirow[t]{2}{*}{ Durable Goods } & -0.0014 & -0.0014 & 0.0018 & $0.0092 * *$ & -0.0016 & -0.0009 & $0.0080 * *$ & 0.0008 & $-0.0062 *$ & $0.0081 *$ \\
\hline & $(0.0090)$ & $(0.0100)$ & $(0.0130)$ & $(0.3630)$ & $(0.0270)$ & $(0.0060)$ & $(0.2940)$ & $(0.0020)$ & $(0.1440)$ & $(0.1520)$ \\
\hline \multirow[t]{2}{*}{ Durable Goods and Real Estate } & 0.0164 & $-0.0329 * *$ & -0.005 & 0.0048 & 0.0152 & $0.0481^{* * *}$ & 0.0089 & 0.0176 & 0.0207 & -0.0322 \\
\hline & $(0.0390)$ & $(0.1580)$ & $(0.0030)$ & $(0.0030)$ & $(0.0740)$ & $(0.4190)$ & $(0.0110)$ & $(0.0270)$ & $(0.0460)$ & $(0.0700)$ \\
\hline \multirow[t]{2}{*}{ Durable Goods and Mortgage } & -0.0315 & 0.0041 & 0.0016 & $0.1018^{* * *}$ & $-0.0326^{*}$ & -0.0279 & $0.0818^{* *}$ & 0.0063 & $-0.0813^{* *}$ & $0.1013^{* *}$ \\
\hline & $(0.0520)$ & $(0.0010)$ & $(0.0000)$ & $(0.4610)$ & $(0.1230)$ & $(0.0510)$ & $(0.3220)$ & $(0.0010)$ & $(0.2550)$ & $(0.2490)$ \\
\hline Traditional CCAPM & 0.0324 & $0.0493^{* * *}$ & 0.0025 & -0.0041 & -0.013 & -0.0223 & 0.0131 & -0.0048 & -0.018 & 0.0289 \\
\hline \multirow[t]{2}{*}{ Durable Goods } & $0.0089 * *$ & 0.0023 & $-0.0033^{* *}$ & $-0.0066^{* * *}$ & $-0.0046^{* *}$ & $-0.0078^{* * *}$ & -0.0005 & $-0.0044^{* *}$ & -0.0062 & -0.0023 \\
\hline & $(0.2530)$ & $(0.0610)$ & $(0.2980)$ & $(0.4080)$ & $(0.2090)$ & $(0.4300)$ & $(0.0010)$ & $(0.3740)$ & $(0.1130)$ & $(0.0430)$ \\
\hline \multirow[t]{2}{*}{ Durable Goods and Real Estate } & $0.0480 * *$ & $0.0223 * *$ & 0.005 & 0.0003 & 0.001 & -0.0128 & $0.0478 * *$ & -0.0036 & -0.0138 & $0.0364 * *$ \\
\hline & $(0.2100)$ & $(0.1590)$ & $(0.0190)$ & $(0.0000)$ & $(0.0000)$ & $(0.0340)$ & $(0.3030)$ & $(0.0070)$ & $(0.0160)$ & $(0.3130)$ \\
\hline \multirow[t]{2}{*}{ Durable Goods and Mortgage } & $0.1025 * *$ & 0.0174 & $-0.0415^{* * *}$ & $-0.0769^{* * *}$ & $-0.0553^{* *}$ & $-0.0777^{* * *}$ & -0.0186 & $-0.0531^{* * *}$ & $-0.0661 *$ & -0.0413 * \\
\hline & $(0.3450)$ & $(0.0350)$ & $(0.4790)$ & $(0.5760)$ & $(0.3130)$ & $(0.4430)$ & $(0.0170)$ & $(0.5610)$ & $(0.1320)$ & $(0.1450)$ \\
\hline \multirow[t]{2}{*}{ Traditional CCAPM } & -0.0205 & -0.0006 & $0.0310 * *$ & 0.0051 & 0.0076 & -0.0319 & $0.0522 * *$ & $0.0232 * *$ & $0.0136^{* *}$ & $0.0538 * *$ \\
\hline & $(0.0670)$ & $(0.0000)$ & $(0.3780)$ & $(0.0050)$ & $(0.0310)$ & $(0.1100)$ & $(0.2770)$ & $(0.2110)$ & $(0.1850)$ & $(0.2240)$ \\
\hline Durable Goods & 0.0026 & $0.0050 * *$ & -0.0008 & $0.0047^{* *}$ & -0.0016 & 0.0015 & -0.0033 & $0.0026 * *$ & -0.001 & -0.0008 \\
\hline \multirow[t]{2}{*}{ Durable Goods and Real Estate } & -0.0007 & 0.0058 & 0.0116 & -0.0022 & $0.0131 * *$ & -0.0119 & 0.0155 & 0.0118 & $0.0106^{* *}$ & $0.0499 * *$ \\
\hline & $(0.0000)$ & $(0.0140)$ & $(0.0920)$ & $(0.0020)$ & $(0.1600)$ & $(0.0270)$ & $(0.0430)$ & $(0.0960)$ & $(0.1970)$ & $(0.3390)$ \\
\hline \multirow[t]{2}{*}{ Durable Goods and Mortgage } & $0.0395^{* *}$ & $0.0585^{* * *}$ & -0.018 & $0.0585^{* * *}$ & $-0.0259 * *$ & 0.0259 & $-0.0539 * *$ & $0.0256^{* *}$ & $-0.0177^{* *}$ & -0.0368 \\
\hline & $(0.1580)$ & $(0.5080)$ & $(0.0810)$ & $(0.4290)$ & $(0.2240)$ & $(0.0460)$ & $(0.1870)$ & $(0.1620)$ & $(0.1980)$ & $(0.0670)$ \\
\hline \multirow[t]{2}{*}{ Traditional CCAPM } & 0.0554 * & -0.0073 & -0.0115 & $0.0557^{* * *}$ & 0.0048 & $-0.0589^{* *}$ & 0.0096 & 0.0106 & 0.0173 & $0.0490 * *$ \\
\hline & $(0.1170)$ & $(0.0020)$ & $(0.0200)$ & $(0.4590)$ & $(0.0030)$ & $(0.2570)$ & $(0.0120)$ & $(0.0080)$ & $(0.0360)$ & $(0.3050)$ \\
\hline \multirow[t]{2}{*}{ Durable Goods } & 0.0054 & $-0.0088^{* *}$ & 0.0022 & -0.0003 & $-0.0057^{* *}$ & -0.0011 & 0.0026 & -0.0007 & $0.0076^{* * *}$ & -0.0011 \\
\hline & $(0.0680)$ & $(0.2170)$ & $(0.0450)$ & $(0.0010)$ & $(0.2800)$ & $(0.0060)$ & $(0.0520)$ & $(0.0030)$ & $(0.4220)$ & $(0.0090)$ \\
\hline \multirow[t]{2}{*}{ Durable Goods and Real Estate } & 0.0227 & $-0.0481 * *$ & 0.0094 & 0.0227 * & 0.007 & $-0.0468^{* *}$ & -0.0173 & 0.0009 & -0.0056 & $0.0430 * * *$ \\
\hline & $(0.0350)$ & $(0.1880)$ & $(0.0240)$ & $(0.1340)$ & $(0.0120)$ & $(0.2850)$ & $(0.0670)$ & $(0.0000)$ & $(0.0070)$ & $(0.4140)$ \\
\hline \multirow[t]{2}{*}{ Durable Goods and Mortgage } & 0.0162 & $-0.0867^{* *}$ & 0.0221 & -0.0199 & $-0.0717^{* * *}$ & 0.0098 & 0.0112 & -0.0324 & $0.0839^{* * *}$ & -0.0231 \\
\hline & $(0.0060)$ & $(0.2200)$ & $(0.0470)$ & $(0.0370)$ & $(0.4630)$ & $(0.0050)$ & $(0.0100)$ & $(0.0500)$ & $(0.5340)$ & $(0.0430)$ \\
\hline
\end{tabular}


Table 8. Cont.

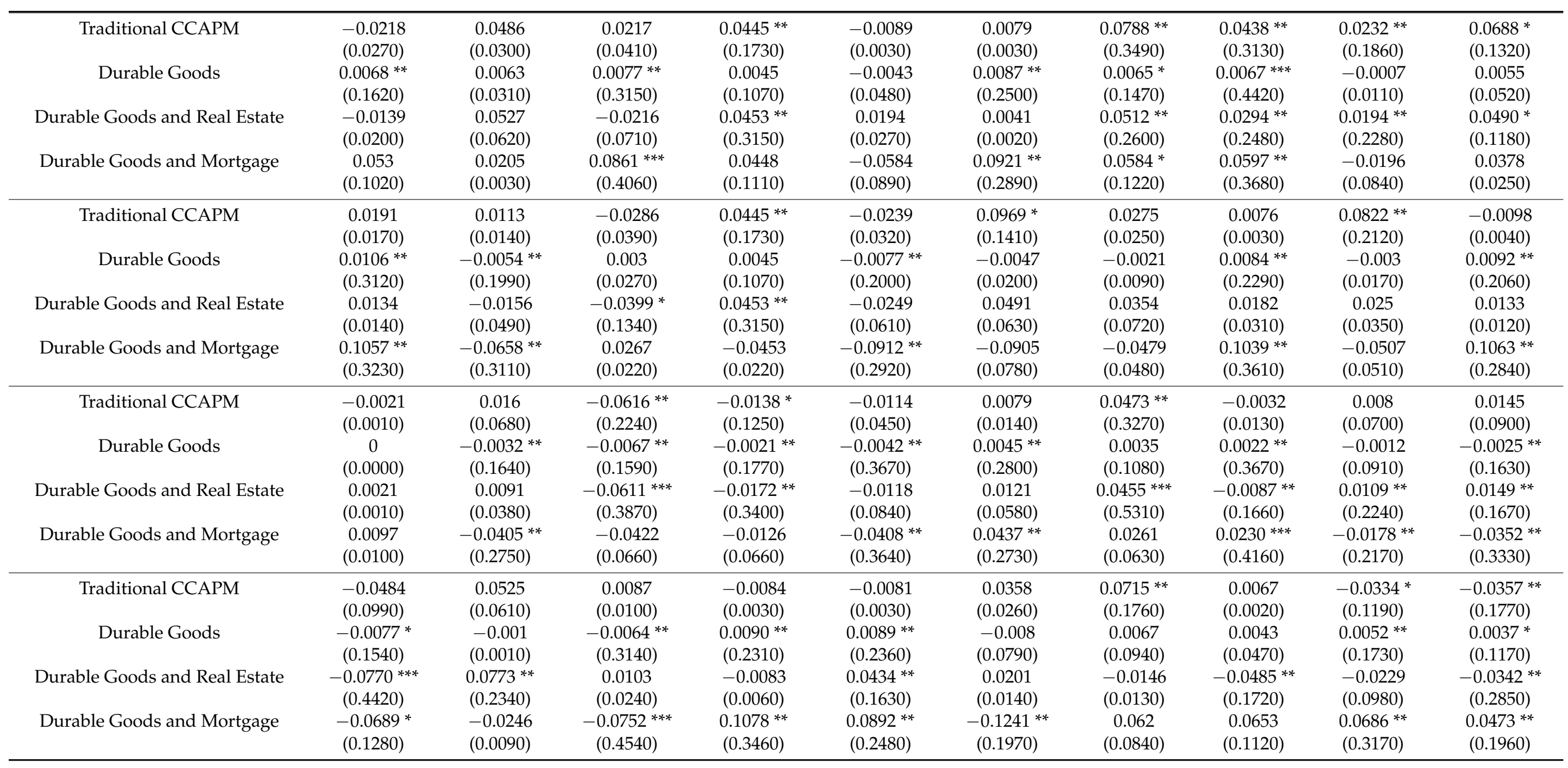


Table 8. Cont.

\begin{tabular}{|c|c|c|c|c|c|c|c|c|c|c|}
\hline Traditional CCAPM & $\begin{array}{c}0.0391 \\
(0.0780)\end{array}$ & $\begin{array}{c}-0.0723 \text { ** } \\
(0.3430)\end{array}$ & $\begin{array}{c}0.0777^{* *} \\
(0.2240)\end{array}$ & $\begin{array}{c}0.0789 \text { ** } \\
(0.3500)\end{array}$ & $\begin{array}{l}-0.0185 \\
(0.0110)\end{array}$ & $\begin{array}{l}-0.0179 \\
(0.0120)\end{array}$ & $\begin{array}{c}0.0393 \\
(0.0670)\end{array}$ & $\begin{array}{c}-0.0318 \\
(0.0150)\end{array}$ & $\begin{array}{c}0.0357 \\
(0.0320)\end{array}$ & $\begin{array}{l}-0.0006 \\
(0.0000)\end{array}$ \\
\hline \multirow{2}{*}{ Durable Goods } & -0.0035 & 0.0014 & 0.003 & 0.0032 & 0.0074 & $-0.0094 * *$ & $-0.0068^{*}$ & -0.0011 & -0.0026 & $0.0084^{* *}$ \\
\hline & $(0.0380)$ & $(0.0080)$ & $(0.0200)$ & $(0.0340)$ & $(0.1100)$ & $(0.2030)$ & $(0.1210)$ & $(0.0010)$ & $(0.0110)$ & $(0.2850)$ \\
\hline \multirow[t]{2}{*}{ Durable Goods and Real Estate } & 0.0401 * & $-0.0330 *$ & $0.0825^{* * *}$ & 0.0253 & $-0.0614^{* *}$ & $0.0506^{* *}$ & -0.0032 & 0.0678 * & 0.0319 & -0.015 \\
\hline & $(0.1450)$ & $(0.1260)$ & $(0.4430)$ & $(0.0630)$ & $(0.2200)$ & $(0.1690)$ & $(0.0010)$ & $(0.1230)$ & $(0.0450)$ & $(0.0260)$ \\
\hline \multirow{2}{*}{ Durable Goods and Mortgage } & -0.0577 & 0.0285 & 0.0156 & 0.0077 & 0.0721 & $-0.0964 * *$ & $-0.0885^{* *}$ & -0.019 & -0.0327 & $0.0970 * * *$ \\
\hline & $(0.1080)$ & $(0.0340)$ & $(0.0060)$ & $(0.0020)$ & $(0.1090)$ & $(0.2210)$ & $(0.2150)$ & $(0.0030)$ & $(0.0170)$ & $(0.3950)$ \\
\hline Traditional CCAPM & 0.0043 & 0.0117 & 0.0307 & $0.0553^{* *}$ & 0.0276 & $-0.0468 *$ & $-0.0256^{* *}$ & 0.0146 & -0.0057 & 0.0045 \\
\hline \multirow[t]{2}{*}{ Durable Goods } & $0.0073^{* *}$ & $0.0066^{* * *}$ & -0.0027 & $0.0553 * *$ & $0.0084^{* *}$ & $-0.0112^{* * *}$ & 0.0017 & -0.0013 & 0.0012 & $-0.0024 *$ \\
\hline & $(0.2010)$ & $(0.4470)$ & $(0.0460)$ & $(0.2870)$ & $(0.3270)$ & $(0.4490)$ & $(0.0730)$ & $(0.0480)$ & $(0.0090)$ & $(0.1400)$ \\
\hline \multirow{2}{*}{ Durable Goods and Real Estate } & 0.0358 * & 0.0132 & $0.0374^{* *}$ & $0.0477^{* *}$ & $0.0387^{* *}$ & -0.031 & $-0.0173 * *$ & 0.0067 & -0.0196 & -0.0011 \\
\hline & $(0.1380)$ & $(0.0510)$ & $(0.2630)$ & $(0.3760)$ & $(0.2010)$ & $(0.0990)$ & $(0.2080)$ & $(0.0390)$ & $(0.0740)$ & $(0.0010)$ \\
\hline \multirow[t]{2}{*}{ Durable Goods and Mortgage } & $0.0689 * *$ & $0.0735^{* * *}$ & $-0.0417^{*}$ & $0.0684^{* *}$ & $0.0829 * *$ & $-0.1199^{* * *}$ & $0.0278^{* *}$ & -0.0193 * & 0.0269 & $-0.0326^{* *}$ \\
\hline & $(0.1850)$ & $(0.5680)$ & $(0.1180)$ & $(0.2790)$ & $(0.3320)$ & $(0.5370)$ & $(0.1940)$ & $(0.1170)$ & $(0.0500)$ & $(0.2740)$ \\
\hline \multirow[t]{2}{*}{ Traditional CCAPM } & 0.0004 & 0.0037 & $0.0547^{* *}$ & $0.0358^{* *}$ & $0.0439 * *$ & $0.1012 * *$ & 0.035 & 0.0213 & 0.0258 & 0.011 \\
\hline & $(0.0010)$ & $(0.0390)$ & $(0.2050)$ & $(0.2570)$ & $(0.1840)$ & $(0.2260)$ & $(0.0410)$ & $(0.0400)$ & $(0.0540)$ & $(0.0180)$ \\
\hline \multirow[t]{2}{*}{ Durable Goods and Real Estate } & $0.0346^{*}$ & -0.0124 & $0.0697^{* * *}$ & $0.0272 * *$ & $0.0570^{* * *}$ & 0.0565 * & $0.0686^{* *}$ & 0.0263 & $0.0478 * *$ & 0.0145 \\
\hline & $(0.1500)$ & $(0.0130)$ & $(0.5860)$ & $(0.2600)$ & $(0.5440)$ & $(0.1240)$ & $(0.2790)$ & $(0.1070)$ & $(0.3290)$ & $(0.0530)$ \\
\hline \multirow[t]{2}{*}{ Durable Goods and Mortgage } & -0.0286 & 0.0512 & 0.0176 & $0.0422 * *$ & -0.0147 & 0.0189 & 0.0452 & $0.0601^{* *}$ & 0.0458 & $0.0718^{* * *}$ \\
\hline & $(0.0370)$ & $(0.0780)$ & $(0.0140)$ & $(0.2270)$ & $(0.0130)$ & $(0.0050)$ & $(0.0440)$ & $(0.2010)$ & $(0.1090)$ & $(0.4710)$ \\
\hline \multirow[t]{2}{*}{ Traditional CCAPM } & 0.0022 & $0.0610^{* *}$ & $0.0644^{* *}$ & 0.0082 & $0.0458 *$ & -0.0053 & 0.002 & $0.0927^{* *}$ & 0.0261 & $0.0391 * *$ \\
\hline & $(0.0000)$ & $(0.2070)$ & $(0.3720)$ & $(0.0040)$ & $(0.1520)$ & $(0.0100)$ & $(0.0020)$ & $(0.2760)$ & $(0.0160)$ & $(0.2040)$ \\
\hline \multirow[t]{2}{*}{ Durable Goods } & 0.0014 & $0.0091^{* *}$ & $0.0067^{* *}$ & $0.0092 * *$ & $0.0086^{* *}$ & $0.0035^{* *}$ & $-0.0036^{* *}$ & $0.0127^{* *}$ & $0.0151 * *$ & -0.0033 \\
\hline & $(0.0070)$ & $(0.2820)$ & $(0.2480)$ & $(0.3020)$ & $(0.3250)$ & $(0.2760)$ & $(0.3040)$ & $(0.3190)$ & $(0.3350)$ & $(0.0880)$ \\
\hline \multirow[t]{2}{*}{ Durable Goods and Real Estate } & 0.0328 & 0.022 & 0.0242 & -0.0145 & 0.0342 * & -0.0095 & 0.0028 & 0.0281 & 0.0347 & 0.0147 \\
\hline & $(0.1000)$ & $(0.0470)$ & $(0.0930)$ & $(0.0220)$ & $(0.1480)$ & $(0.0580)$ & $(0.0050)$ & $(0.0450)$ & $(0.0510)$ & $(0.0510)$ \\
\hline \multirow[t]{2}{*}{ Durable Goods and Mortgage } & -0.0149 & $0.0856^{* *}$ & $0.0627^{* *}$ & $0.1042^{* * *}$ & $0.0672^{* *}$ & $0.0443^{* * *}$ & $-0.0448^{* * *}$ & $0.1214^{* *}$ & $0.1312 * *$ & $-0.0540 * *$ \\
\hline & $(0.0070)$ & $(0.2580)$ & $(0.2230)$ & $(0.4030)$ & $(0.2070)$ & $(0.4600)$ & $(0.4820)$ & $(0.3010)$ & $(0.2630)$ & $(0.2480)$ \\
\hline
\end{tabular}


Table 8. Cont.

\begin{tabular}{|c|c|c|c|c|c|c|c|c|c|c|}
\hline Traditional CCAPM & $\begin{array}{c}-0.0398 * \\
(0.1450)\end{array}$ & $\begin{array}{c}0.053 \\
(0.0920)\end{array}$ & $\begin{array}{c}0.0607^{* *} \\
(0.2460)\end{array}$ & $\begin{array}{c}0.0236 \\
(0.0540)\end{array}$ & $\begin{array}{c}0.0018 \\
(0.0010)\end{array}$ & $\begin{array}{l}-0.0041 \\
(0.0030)\end{array}$ & $\begin{array}{c}0.0099 \\
(0.0030)\end{array}$ & $\begin{array}{c}0.0439 \\
(0.0820)\end{array}$ & $\begin{array}{c}0.0691 \\
(0.0660)\end{array}$ & $\begin{array}{c}0.0248 \\
(0.0200)\end{array}$ \\
\hline \multirow[t]{2}{*}{ Durable Goods } & 0.0034 & $0.0075^{*}$ & $0.0087 * *$ & $-0.0059 * *$ & $-0.0036^{* *}$ & $-0.0056^{* *}$ & 0.0041 & $0.0110 * *$ & 0.0085 & $0.0166^{* * *}$ \\
\hline & $(0.0650)$ & $(0.1130)$ & $(0.3080)$ & $(0.2060)$ & $(0.1710)$ & $(0.3050)$ & $(0.0300)$ & $(0.3120)$ & $(0.0610)$ & $(0.5330)$ \\
\hline \multirow[t]{2}{*}{ Durable Goods and Real Estate } & $-0.0451^{* *}$ & $0.0933^{* * *}$ & $0.0417^{* *}$ & 0.0093 & $0.0200 *$ & 0.003 & 0.04 & $0.0587^{* *}$ & $0.0832 * *$ & -0.0107 \\
\hline & $(0.3270)$ & $(0.4990)$ & $(0.2040)$ & $(0.0150)$ & $(0.1500)$ & $(0.0030)$ & $(0.0810)$ & $(0.2580)$ & $(0.1680)$ & $(0.0060)$ \\
\hline \multirow[t]{2}{*}{ Durable Goods and Mortgage } & 0.0398 & 0.0573 & $0.0729 * *$ & $-0.0790^{* * *}$ & $-0.0485^{* *}$ & $-0.0666^{* * *}$ & 0.0336 & $0.1108^{* *}$ & 0.0882 & $0.1636^{* * *}$ \\
\hline & $(0.0920)$ & $(0.0680)$ & $(0.2240)$ & $(0.3840)$ & $(0.3180)$ & $(0.4460)$ & $(0.0210)$ & $(0.3300)$ & $(0.0680)$ & $(0.5380)$ \\
\hline Traditional CCAPM & $0.0490 * *$ & -0.0319 & $-0.0626^{*}$ & -0.005 & 0.0358 & -0.0203 & 0.0283 & -0.0424 & $-0.0186^{*}$ & $0.0147 *$ \\
\hline \multirow[t]{2}{*}{ Durable Goods } & 0.0047 & $-0.0107^{* *}$ & $-0.0116^{* *}$ & $0.0069 * *$ & $0.0075^{* *}$ & $0.0055^{* *}$ & -0.0033 & $-0.0118^{* * *}$ & $0.0025^{* *}$ & $-0.0025^{* *}$ \\
\hline & $(0.1040)$ & $(0.2580)$ & $(0.2470)$ & $(0.3060)$ & $(0.1920)$ & $(0.3200)$ & $(0.0290)$ & $(0.5210)$ & $(0.1650)$ & $(0.2180)$ \\
\hline \multirow[t]{2}{*}{ Durable Goods and Real Estate } & $0.0571^{* * *}$ & 0.02 & $-0.0729^{* *}$ & -0.0067 & $0.0521 * *$ & $-0.0262 * *$ & $0.0544^{* *}$ & -0.0097 & -0.0085 & 0.0103 \\
\hline & $(0.4460)$ & $(0.0260)$ & $(0.2820)$ & $(0.0080)$ & $(0.2670)$ & $(0.2110)$ & $(0.2280)$ & $(0.0100)$ & $(0.0540)$ & $(0.1030)$ \\
\hline \multirow[t]{2}{*}{ Durable Goods and Mortgage } & 0.0372 & $-0.0939 * *$ & $-0.1101^{* *}$ & $0.0839 * * *$ & $0.0794 * *$ & $0.0641^{* * *}$ & -0.0523 & $-0.1208^{* * *}$ & $0.0303 * *$ & $-0.0333^{* * *}$ \\
\hline & $(0.0680)$ & $(0.2070)$ & $(0.2310)$ & $(0.4690)$ & $(0.2240)$ & $(0.4570)$ & $(0.0760)$ & $(0.5650)$ & $(0.2500)$ & $(0.3870)$ \\
\hline \multirow[t]{2}{*}{ Traditional CCAPM } & $0.0389 * *$ & -0.0048 & 0.0136 & $-0.0221 *$ & 0.0093 & $0.0192 * *$ & -0.0137 & -0.0151 & -0.0011 & -0.0118 \\
\hline & $(0.2780)$ & $(0.0040)$ & $(0.0300)$ & $(0.1490)$ & $(0.0100)$ & $(0.1690)$ & $(0.0760)$ & $(0.0950)$ & $(0.0000)$ & $(0.0810)$ \\
\hline Durable Goods & $0.0036^{*}$ & 0.0027 & 0.0018 & 0.0008 & $0.0078^{* * *}$ & -0.0019 & -0.0004 & $0.0023 *$ & 0.0028 & $-0.0040^{* * *}$ \\
\hline \multirow[t]{2}{*}{ Durable Goods and Real Estate } & $0.0431^{* * *}$ & $-0.0279 * *$ & $0.0246^{* *}$ & -0.0018 & 0.0193 & $0.0197 * *$ & 0.0104 & $-0.0229^{* * *}$ & -0.0296 & -0.0101 \\
\hline & $(0.5990)$ & $(0.2420)$ & $(0.1710)$ & $(0.0020)$ & $(0.0770)$ & $(0.3150)$ & $(0.0770)$ & $(0.3850)$ & $(0.0970)$ & $(0.1040)$ \\
\hline \multirow[t]{2}{*}{ Durable Goods and Mortgage } & 0.0255 & 0.0368 * & 0.0004 & 0.0044 & $0.0803^{* * *}$ & $-0.0261 * *$ & -0.0107 & $0.0294^{* *}$ & 0.0325 & $-0.0424^{* * *}$ \\
\hline & $(0.0750)$ & $(0.1510)$ & $(0.0000)$ & $(0.0040)$ & $(0.4780)$ & $(0.1990)$ & $(0.0290)$ & $(0.2270)$ & $(0.0420)$ & $(0.6560)$ \\
\hline \multirow[t]{2}{*}{ Traditional CCAPM } & 0.02 & $-0.0247^{* *}$ & $0.0835^{* * *}$ & 0.0489 & -0.0177 & -0.0367 & -0.0037 & & & \\
\hline & $(0.0480)$ & $(0.1760)$ & $(0.4700)$ & $(0.0860)$ & $(0.0660)$ & $(0.0760)$ & $(0.0070)$ & & & \\
\hline \multirow[t]{2}{*}{ Durable Goods } & $0.0049^{* *}$ & 0.0011 & 0.0024 & -0.0029 & $0.0047^{* *}$ & -0.0044 & $-0.0034 * *$ & & & \\
\hline & $(0.1790)$ & $(0.0220)$ & $(0.0230)$ & $(0.0180)$ & $(0.2890)$ & $(0.0680)$ & $(0.3340)$ & & & \\
\hline \multirow[t]{2}{*}{ Durable Goods and Real Estate } & 0.0188 & $-0.0169 *$ & 0.0265 & $0.0627 * *$ & -0.014 & 0.0084 & 0.0025 & & & \\
\hline & $(0.0750)$ & $(0.1450)$ & $(0.0830)$ & $(0.2480)$ & $(0.0720)$ & $(0.0070)$ & $(0.0050)$ & & & \\
\hline \multirow[t]{2}{*}{ Durable Goods and Mortgage } & $0.0547^{* *}$ & 0.0112 & 0.0108 & -0.062 & $0.0569^{* * *}$ & -0.0403 & $-0.0400^{* * *}$ & & & \\
\hline & $(0.2290)$ & $(0.0230)$ & $(0.0050)$ & $(0.0870)$ & $(0.4310)$ & $(0.0580)$ & $(0.4910)$ & & & \\
\hline
\end{tabular}


Panel A: Investment in Housing as a Measure of Real Estate Growth

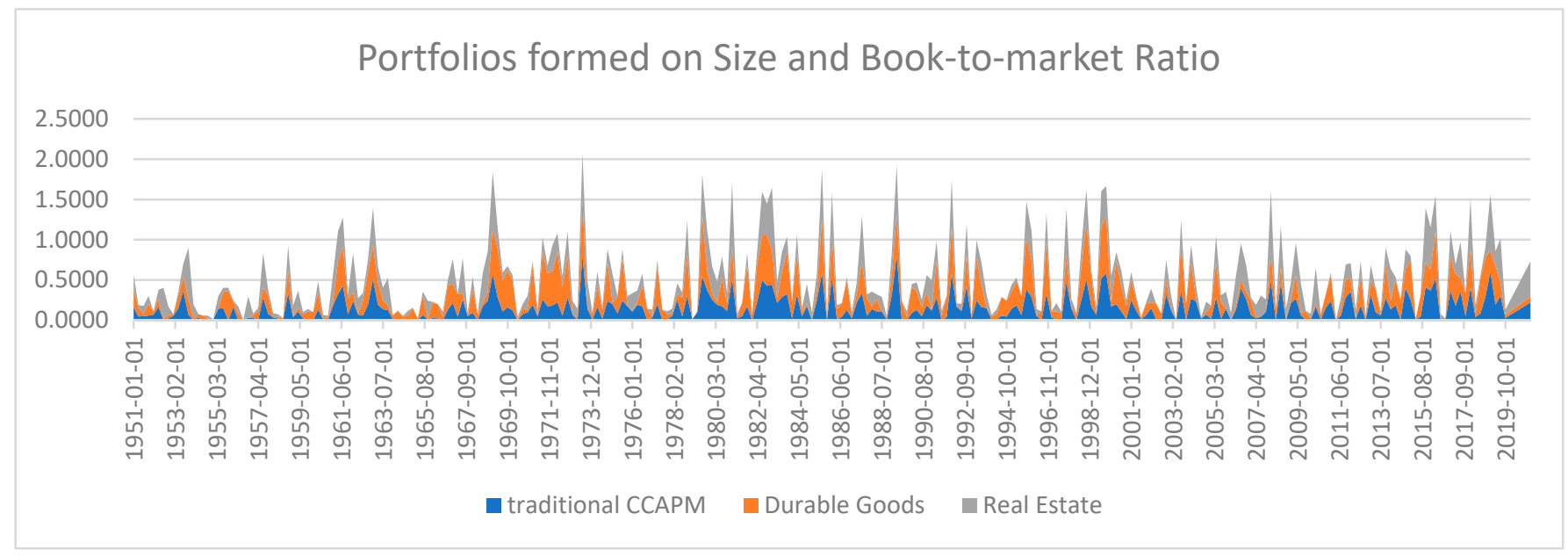

Panel B: Housing Mortgage as a Measure of Real Estate Growth

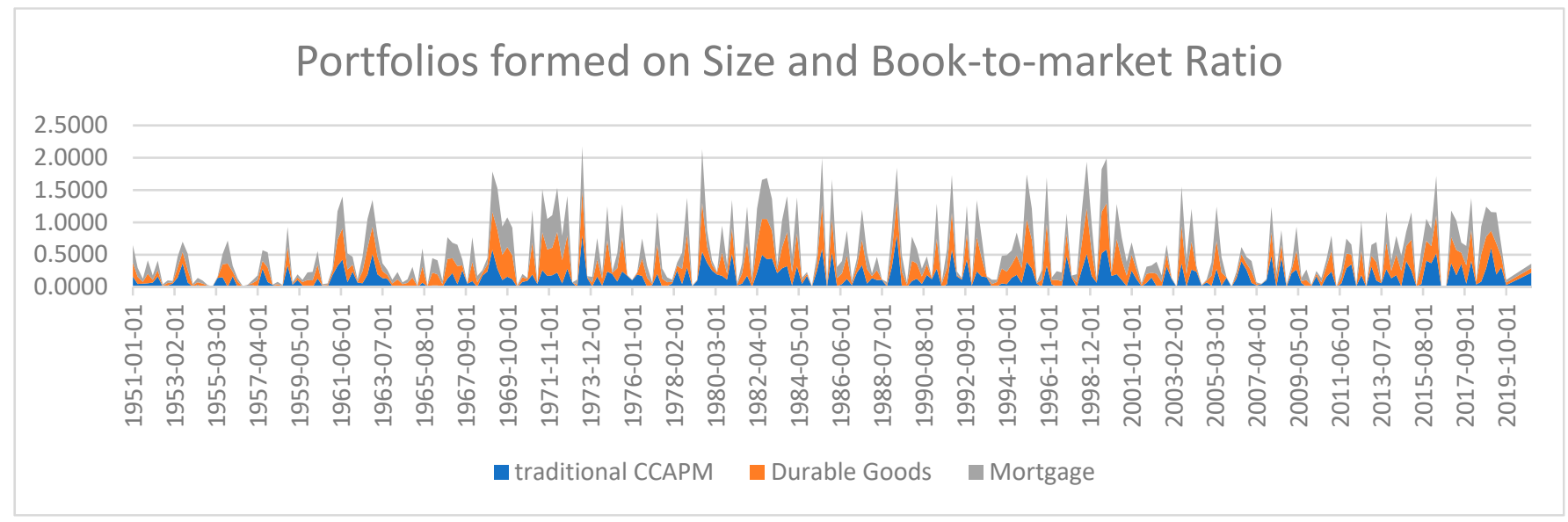

Figure 1. Comparison between Different Models Based on the Portfolios Formed on Size and BookTo-Market Ratio. (Panel (A)) indicates the comparison among three models. The blue one is the fluctuation of adjusted R-squares for traditional CCAPM; the red one represents the fluctuation of adjusted R-squares for the model containing consumptions of durable goods, nondurable goods, and services; the green one is the fluctuation of adjusted R-squares for the model including consumptions of durable goods, nondurable goods, services, and investment in real estate. The time period is from 1952 Q1 to 2021 Q1. (Panel (B)) indicates the comparison among three models. The blue one is the fluctuation of adjusted R-squares for traditional CCAPM; the red one represents the fluctuation of adjusted R-squares for the model containing consumptions of durable goods, nondurable goods and services; the green one is the fluctuation of adjusted R-squares for the model containing consumptions of durable goods, nondurable goods, services and housing mortgage. The time period is from $1952 \mathrm{Q} 1$ to 2021 Q1.

Table 9. Comparison of adjusted R-Squares between Different Portfolios.

\begin{tabular}{lrrrr}
\hline & Traditional CCAPM & Durable Goods & Real Estate & Mortgage \\
\hline Portfolios formed on Size and Book-to-market & 0.1247 & 0.1584 & 0.1429 & 0.1708 \\
Portfolios formed on Size and Short-term Reversal & 0.0880 & 0.1270 & 0.1119 & 0.1482 \\
\hline
\end{tabular}


Panel A: Investment in Housing as a Measure of Real Estate Growth

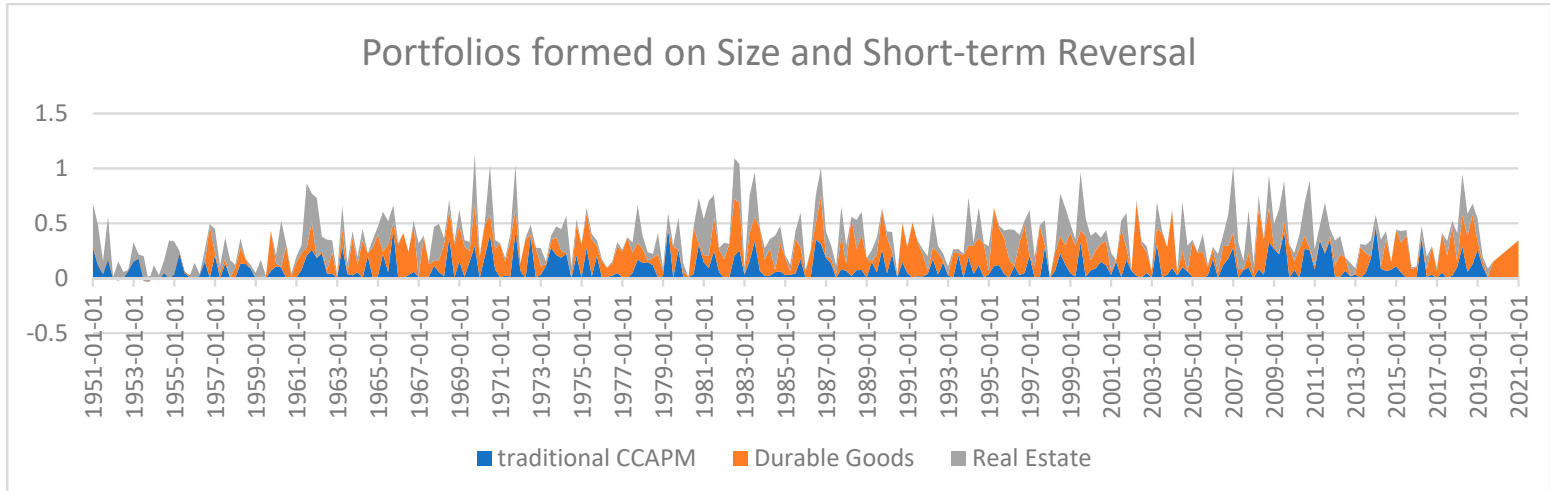

Panel B: Housing Mortgage as a Measure of Real Estate Growth

Portfolios formed on Size and Short-term Reversal

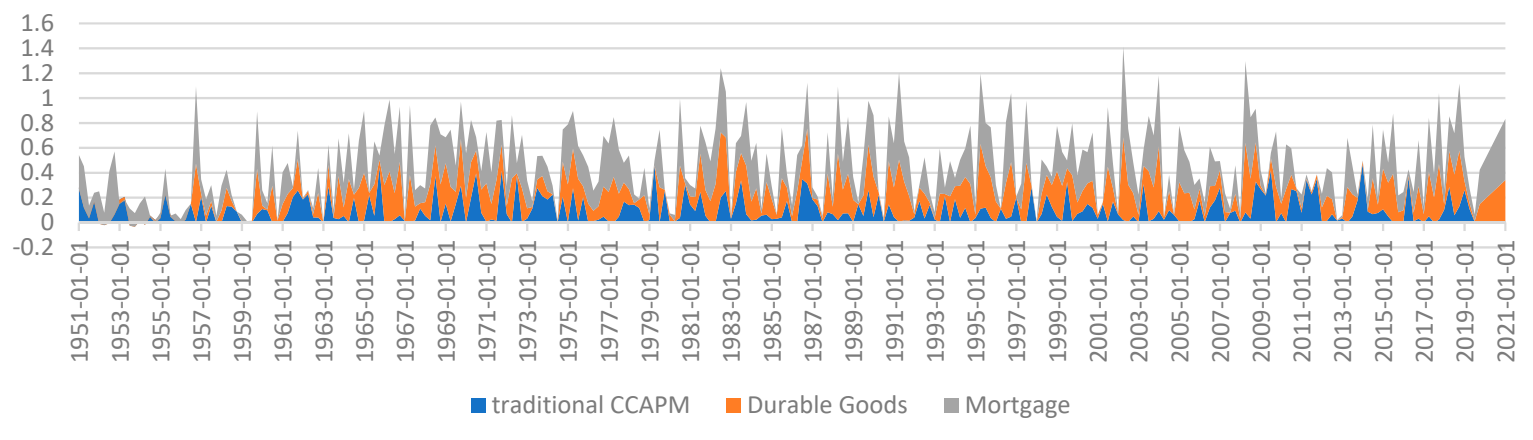

Figure 2. Comparison between Different Models Based on the Portfolios Formed on Size and Short-term Reversal. (Panel (A)) indicates the comparison among three models. The blue one is the fluctuation of adjusted R-squares for traditional CCAPM; the red one represents the fluctuation of adjusted $\mathrm{R}$-squares for the model containing consumptions of durable goods, nondurable goods, and services; the green one is the fluctuation of adjusted $\mathrm{R}$-squares for the model containing consumptions of durable goods, nondurable goods, services, and investment in real estate. The time period is from 1952 Q1 to 2021 Q1. (Panel (B)) indicates the comparison among three models. The blue one is the fluctuation of adjusted R-squares for traditional CCAPM; the red one represents the fluctuation of adjusted $\mathrm{R}$-squares for the model containing consumptions of durable goods, nondurable goods, and services; the green one is the fluctuation of adjusted R-squares for the model containing consumptions of durable goods, nondurable goods, services, and housing mortgage. The time period is from 1952 Q1 to 2021 Q1.

\subsection{Effects of Stock Market}

Since the portfolios are formed into two categories: one is formed on size and book-to market ratio and the other is formed on size and short-term reverse, this part contains two types of stock portfolio. Thus, we select two ways of forming the portfolios: one is based on the size and book-to-market ratio, the other is formed on size and short-term reversal.

Table 9 shows the average adjusted R-squares in two kinds of portfolios. In this table, we find that in size and book-to-market based portfolios, the average adjusted R-square is 0.1247 in traditional CCAPM and it increases to 0.1584 when we add the factor of durable goods consumption in the model. Furthermore, it grows to 0.1429 and 0.1708 when investment in real estate and housing mortgage factors are contained respectively.

In another portfolio formed on size and short-term reversal, it shows clearly that the value of adjusted R-square goes up from 0.0880 to 0.1482 when the factor of investment in real estate is added into the model. In short, both of them suggest that the more elements that influence the consumption market are added, the greater the values of adjusted R-squares will be. 
Besides according to these two groups of figures in Table 9, it indicates that the value of adjusted R-square is higher in the size and short-term reversal formed portfolios than in the portfolios formed on size and book-to-market ratio. That is to say, size and short-term reversal formed portfolios are more significant for our model. In other words, the formation of the stock portfolios has an influence on the results.

Meanwhile learning from Panel A in Figure 3, we find that in traditional CCAPM, the values of adjusted R-square are roughly greater by using the portfolios formed on size and book-to-market ratio than ones based on size and short-term reversal. Furthermore, as more consumption elements are added, this trend keeps on. Thus, the formation of stock portfolios also plays a significant role in the model.

Panel A: Comparison of Adjusted R-Squares in Traditional CCAPM between Two Kinds of Portfolios

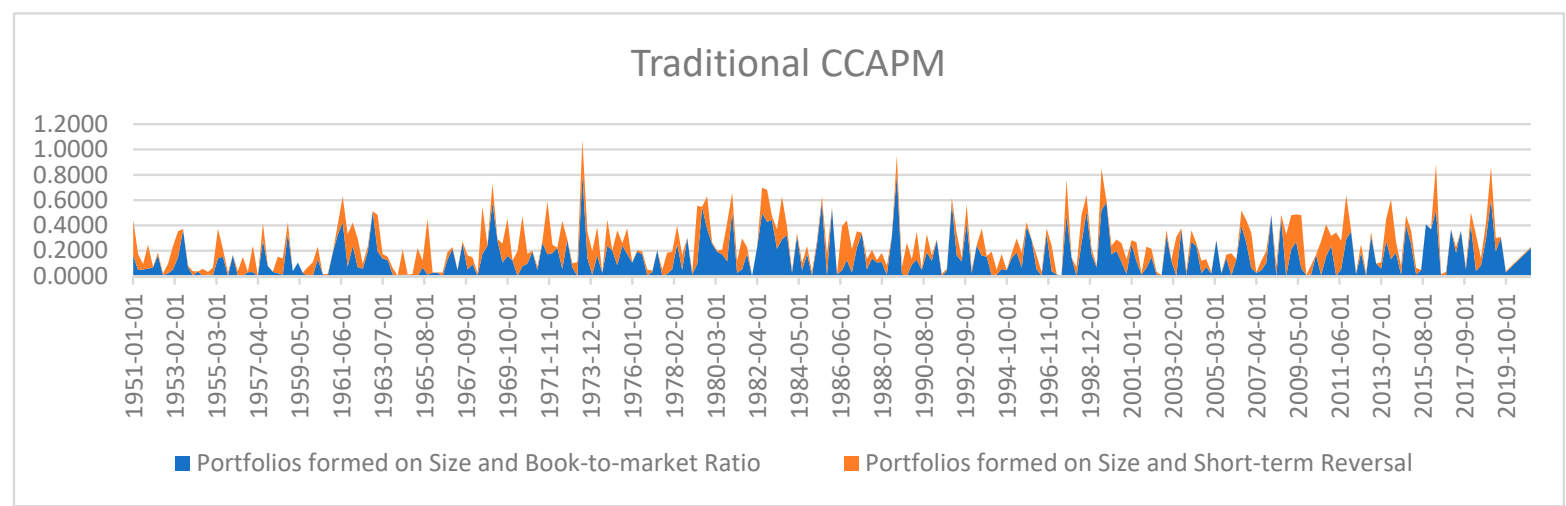

Panel B: Comparison of Adjusted R-Squares in Model with Consumption Factors of Durable Goods, Nondurable Goods and Services between Two Kinds of Portfolios

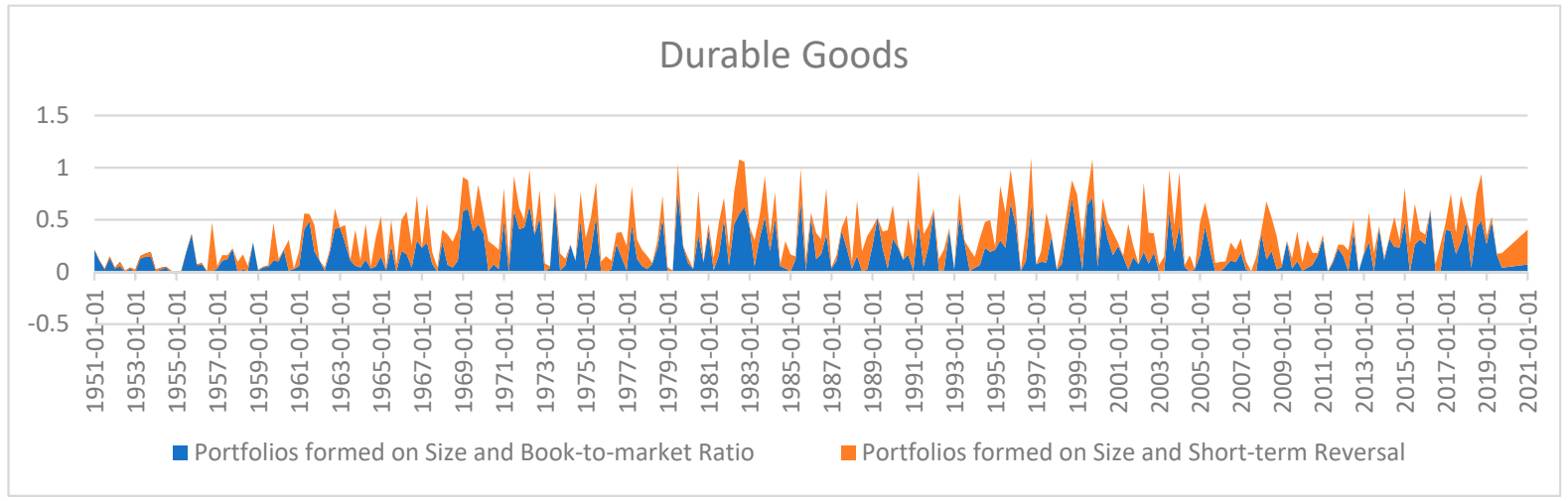

Panel C: Comparison of Adjusted R-Squares in Model with Consumption Factors of Durable Goods, Nondurable Goods Services and Investment in Real Estate between Two Kinds of Portfolios

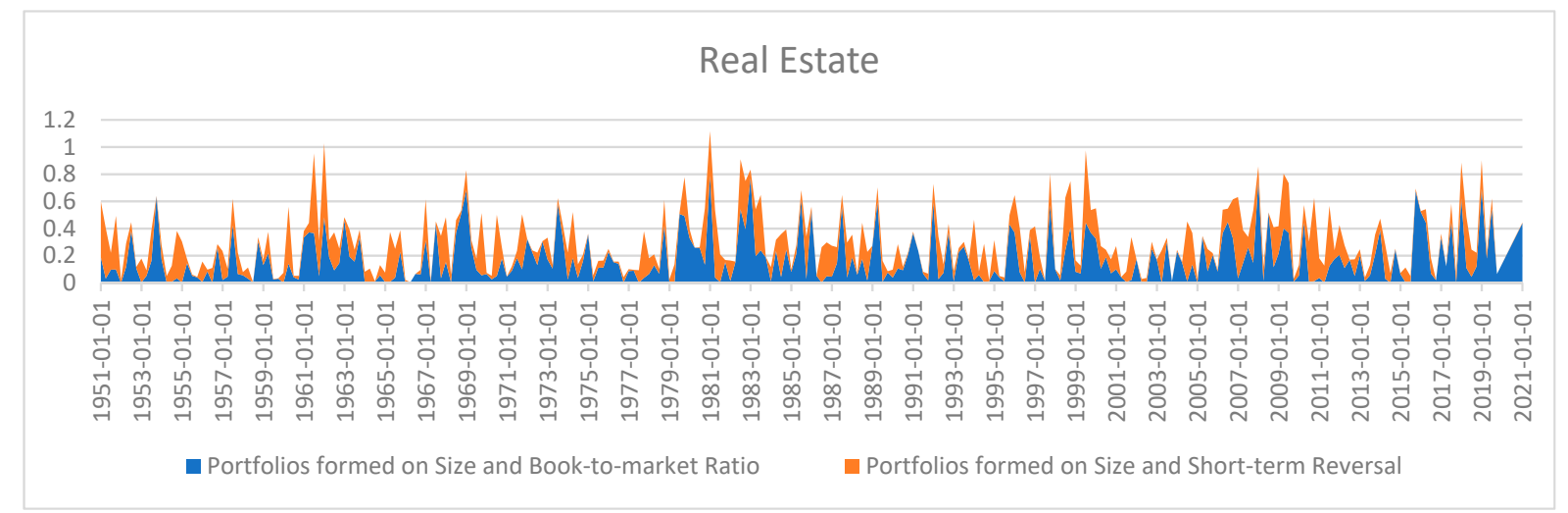

Figure 3. Cont. 
Panel D: Comparison of Adjusted R-Squares in Model with Consumption Factors of Durable Goods, Nondurable Goods Services and Housing Mortgage between Two Kinds of Portfolios

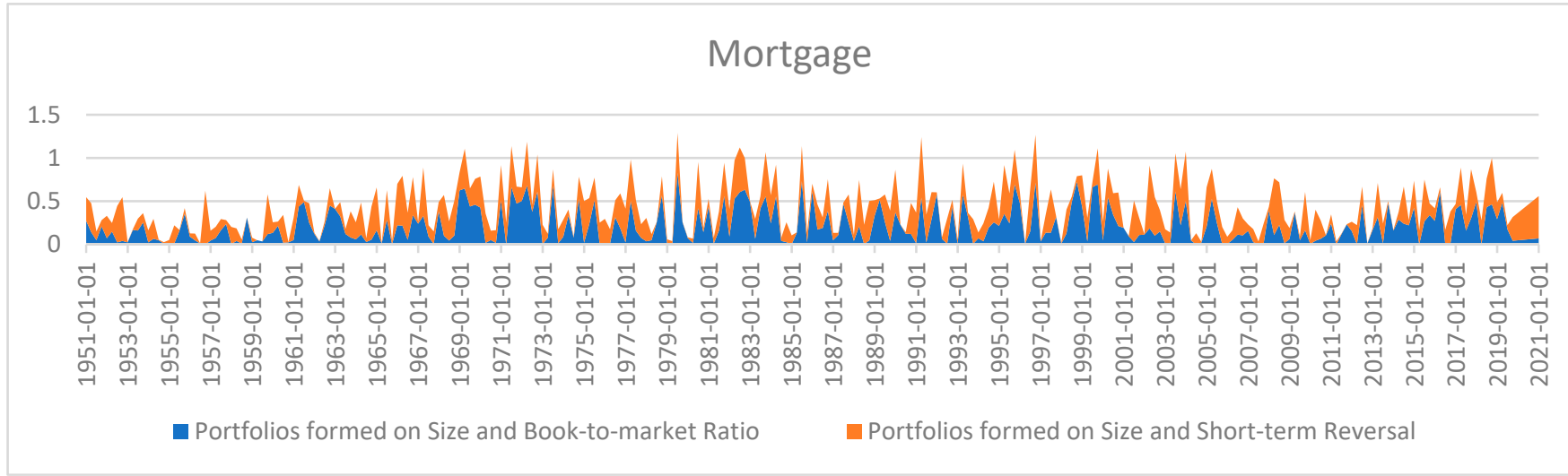

Figure 3. Comparison between Different Portfolios. (Panel (A)) indicates the comparison between two kinds of portfolios. The blue one is the adjusted R-Squares in traditional CCAMP based on portfolios formed on size and short-term reversal; while the green one represents the adjusted $\mathrm{R}$-Squares in traditional CCAMP based on portfolios formed on size and book-to-market ratio. The time period is from 1952 Q1 to 2021 Q1. (Panel (B)) indicates the comparison between two kinds of portfolios. The blue one is the adjusted R-Squares in model with consumption factors of durable goods, nondurable goods and services based on portfolios formed on size and short-term reversal; while the green one represents the adjusted $\mathrm{R}$-Squares in model based on portfolios formed on size and book-to-market ratio. The time period is from 1952 Q1 to 2021 Q1. (Panel (C)) indicates the comparison between two kinds of portfolios. The blue one is the adjusted $\mathrm{R}$-Squares in model with consumption factors of durable goods, nondurable goods services and investment in real estate based on portfolios formed on size and short-term reversal; while the green one represents the adjusted $\mathrm{R}$-Squares in model based on portfolios formed on size and book-to-market ratio. The time period is from 1952 Q1 to 2021 Q1. (Panel (D)) indicates the comparison between two kinds of portfolios. The blue one is the adjusted R-Squares in model with consumption factors of durable goods, nondurable goods services and investment in housing mortgage based on portfolios formed on size and shortterm reversal; while the green one represents the adjusted $\mathrm{R}$-Squares in model based on portfolios formed on size and book-to-market ratio. The time period is from 1952 Q1 to 2021 Q1.

\subsection{Portfolios Sorted on Size and Short-Term Reversal}

Apart from the consumption factors that influence the final results, we still consider the stock elements which may also affect the results. Thus, we select two ways of forming the portfolios: one is based on the size and book-to-market ratio, the other is formed on size and short-term reversal.

\section{Panel Data Analysis}

It has been proved that illiquidity and fluctuations in real estate value, which is undoubtedly the largest share of household portfolios, can increase consumption risk and trigger financial crisis (Huh and Kim, 2021 [34]; Eiling et al., 2019 [35]; Liu et al., 2013 [36]). Learning from the history of American financial crisis, we find that changes in the real estate have an indelible effect on the US financial market. In order to comprehensively understand the effects of real estate on financial market, we run the regression in these two kinds of portfolios with CCAPM containing different factors.

\subsection{Full Sample Regressions}

In this part, we take the full sample from 1952 Q1 to 2021 Q1. The regression results of portfolios formed on size and book-to-market with CCAPM containing different factors are shown in Table 10. It shows that the asset pricing model with durable goods can better explain the changes in capital market, while the model with real estate cannot reflect the 
shifts in stock market. However, it is not the case in Table 11, which displays the regression results of portfolios formed on size and short-term reversal with CCAPM containing different factors. In Table 11, we can learn that the addition of real estate market factors can better explain the rate of return in capital market.

Table 10. Regression Results of portfolios formed on size and book-to-market from 1952 Q1 to 2021 Q1.

\begin{tabular}{ccccc}
\hline & Traditional CCAPM & Durable Goods & Durable Goods and Real Estate & Durable Goods and Mortgage \\
\hline coefficient & -714.977 & $4458.363 *$ & 397.4273 & -2532.897 \\
T-value & -0.83 & 2.01 & 0.54 & -1.28 \\
\hline
\end{tabular}

Note: significance level is denoted by ${ }^{*}$, which corresponds to the $10 \%$, level.

Table 11. Regression Results of portfolios formed on size and short-term reversal 1952 Q1 to 2021 Q1.

\begin{tabular}{ccccc}
\hline & Traditional CCAPM & Durable Goods & Durable Goods and Real Estate & Durable Goods and Mortgage \\
\hline coefficient & -3971.675 & $8823.567^{*}$ & 1141.787 & $-5967.786^{* * *}$ \\
T-value & -1.00 & 1.95 & 1.20 & -3.95 \\
\hline
\end{tabular}

Note: significance levels are denoted by ${ }^{*}, * * *$, which correspond to the $10 \%$, and $1 \%$ levels, respectively.

\subsection{Sub-Sample Regressions}

To better understand the relation between real estate and stock market, we provide sub-sample regressions.

There were 2 financial crises in the US during the sample period: 1 was in 1988 and the other was in 2008. On 19 October 1987, it happened "Black Monday" in US, the Dow Jones industrial stock of the United States fell 508 points, or 22.6\%. Turid (1989) [37] believes that the occurrence of the crisis is only a manifestation of problems in government management mechanism. It is mainly because of the inappropriate treatment among factors in the economy. Apart from the sharp decline in stock market, there were also substantial price fluctuations in oil and other commodity markets (Samii 1988 [38]). Meanwhile, there was a significant price reduction in real estate (Edwards, 1988 [39]). However, a subprime mortgage crisis happened in 2008 in US. Different from the 1988 financial crisis, this financial crisis was caused by the subprime mortgage crisis in the real estate market (Deni et al., 2021 [40]). Antónioet al. (2020) [41] also revisit the relationship between economic growth and financial development. They conclude that there exists an interaction between financial development and economic growth in GMM model.

Learning from Tables 12-14, the addition of durable consumer goods can make the asset pricing model more effectively before the second financial crisis. However, it is not true from 2009 Q1 to 2021 Q1. It is mainly because the mortgage crisis is the source of financial crisis in US from 2008, which is directly related to the real estate market bubble. The outbreak of the financial crisis has caused the US real estate market to drop about $30 \%$ directly, and the capital market has also been hit hard, which made the US aware of its financial policy mistakes. The crisis led the United States to pay more attention to financial supervision and stricter supervision of the real estate market. More importantly, the outbreak of the financial crisis had a great psychological impact on people, resulting in a very low expectation of real estate.

Table 12. Regression Results of portfolios formed on size and book-to-market from 1952 Q1 to 1987 Q4.

\begin{tabular}{ccccc}
\hline & Traditional CCAPM & Durable Goods & Durable Goods and Real Estate & Durable Goods and Mortgage \\
\hline coefficient & -593.4991 & $5346.244^{*}$ & -9.76455 & -2054.592 \\
T-value & -0.5 & 1.76 & -0.01 & -0.76 \\
\hline
\end{tabular}

Note: significance level is denoted by ${ }^{*}$, which corresponds to the $10 \%$ level. 
Table 13. Regression Results of portfolios formed on size and book-to-market from 1988 Q1 to 2008 Q4.

\begin{tabular}{ccccc}
\hline & Traditional CCAPM & Durable Goods & Durable Goods and Real Estate & Durable Goods and Mortgage \\
\hline coefficient & -1405.042 & $6512.049 *$ & 752.2156 & -3574.18 \\
T-value & -0.94 & 1.70 & 0.59 & -1.04 \\
\hline
\end{tabular}

Note: significance level is denoted by ${ }^{*}$, which corresponds to the $10 \%$ level.

Table 14. Regression Results of portfolios formed on size and book-to-market from 2009 Q1 to 2021 Q1.

\begin{tabular}{ccccc}
\hline & Traditional CCAPM & Durable Goods & Durable Goods and Real Estate & Durable Goods and Mortgage \\
\hline coefficient & 110.9902 & -1671.528 & 985.8642 & -2153.467 \\
T-value & 0.05 & -0.29 & 0.52 & -0.42 \\
\hline
\end{tabular}

Meanwhile, we regress the portfolios formed on size and short-term reversal in these three periods. From Tables 15-17, it reverses that adding the real estate factor into the asset pricing model can well explain the capital market return, but it is only effective before the outbreak of the first financial crisis in 1988. Since the financial crisis, numerous studies have confirmed that the liquidity of American real estate is very poor after the financial crisis (Ellington et al., 2017 [42]; Ellington et al., 2021 [43]; Baker et al., 2016 [44]). Therefore, we believe that due to the outbreak of the financial crisis, the adjustment of real estate policies weakens the ability of real estate to explain the capital market.

Table 15. Regression Results of portfolios formed on size and short-term reversal from 1952 Q1 to 1987 Q4.

\begin{tabular}{ccccc}
\hline & Traditional CCAPM & Durable Goods & Durable Goods and Real Estate & Durable Goods and Mortgage \\
\hline coefficient & -5908.321 & $12403.9 * *$ & 1172.098 & $-7658.789 * * *$ \\
T-value & -1.10 & 2.03 & 0.91 & -3.74 \\
\hline
\end{tabular}

Note: significance levels are denoted by ${ }^{* *}, * *$, which correspond to the $5 \%$, and $1 \%$ levels, respectively.

Table 16. Regression Results of portfolios formed on size and short-term reversal from 1988 Q1 to 2008 Q4.

\begin{tabular}{ccccc}
\hline & Traditional CCAPM & Durable Goods & Durable Goods and Real Estate & Durable Goods and Mortgage \\
\hline coefficient & -1871.832 & 6163.453 & 962.619 & -4248.296 \\
T-value & -0.27 & 0.77 & 0.57 & -1.59 \\
\hline
\end{tabular}

Table 17. Regression Results of portfolios formed on size and short-term reversal from 2009 Q1 to 2021 Q1.

\begin{tabular}{ccccc}
\hline & Traditional CCAPM & Durable Goods & Durable Goods and Real Estate & Durable Goods and Mortgage \\
\hline coefficient & -1880.036 & 2861.979 & 1359.852 & -3946.002 \\
T-value & -0.18 & 0.25 & 0.55 & -1.01 \\
\hline
\end{tabular}

\section{Conclusions}

Following the pace of previous scholars on the empirical research in traditional CCAPM, we extend the model by adding consumption factors and transforming portfolios based on traditional CCAPM. Our main purpose is to test whether the model is effective in reality and then we can use it to measure the risk and finally control the risk both in stock market and consumption market. Our model indicates that consumption factors-such as consumption of durable goods, nondurable goods, services, and investment in housing-play a vital role in measuring market risks. Likewise, totally overlooking the formation of the portfolio can also generate mistakes in evaluating the market risks. Furthermore, with the result of robust, we are confidential in considering that stock market and consumption market are correlated with each other. 
Additionally, our paper emphasizes the issue of real estate's influence on the stock market through the channel of consumption. Through addressing this issue, our paper delivers three main research implications. First, our paper establishes the connection between the real estate market and the stock market. Secondly, our results enhance the asset pricing model by incorporating the interactions between real estate investment and consumption. Finally, we constitute a risk measure to contain the mortgage risk into the asset pricing model, calibrating the systematic risk in financial system.

However, there are still some shortages in the paper. First of all, the model is effectiveness only in US. We have not tested it by using the figures in other countries. Secondly, from the analysis above, we find that the data about the consumption of real estate is slightly different since they are collecting from two ways. It leads to some slight differences in the results. Thirdly, more factors should be contained. However, because of the limited space, we can only test these four main factors in the model. For the future work, we can include other factors into the CAPM for the empirical verification such as the company profitability (see Guaita-Pradas and Blasco-Ruiz, 2020 [45]; Lin, 2021 [46]), especially the profitability of real estate companies as well the momentum factor (see Ayub et al., 2020 [47]; Nasir et al., 2021 [48]). In particular, we will focus on the momentum effect for the real estate sector.

Author Contributions: Conceptualization, S.D. and T.C.; methodology, D.Z.; validation, D.Z., S.D. and H.J.; formal analysis, S.D.; investigation, D.Z.; resources, H.J.; data curation, D.Z.; writingoriginal draft preparation, D.Z; ; writing — review and editing, S.D.; visualization, D.Z.; supervision, T.C.; project administration, T.C.; funding acquisition, S.D. All authors have read and agreed to the published version of the manuscript.

Funding: This research was supported by the Academy of Longyuan Construction Financial Research, Ningbo University, with the Research Grant "Study on Blockchain Financing for Infrastructure Firms" (Grant Number: LYZDB2004). The Academy of Longyuan Construction Financial Research was jointly funded by Business School of Ningbo University and Longyuan Group, aiming for training modern enterprise application-oriented and compounded talents for the construction industry. This research was also supported by University of Nottingham NRG grant (Grant Number: I03211200008).

Institutional Review Board Statement: Not applicable.

Informed Consent Statement: Not applicable.

Data Availability Statement: The NIPA data used to support the findings of this study are available from the corresponding author upon request.

Conflicts of Interest: The authors declare no conflict of interest.

\section{References}

1. Sharpe, W. Capital Asset Prices: A Theory of Market Equilibrium under Conditions of Risk. J. Financ. 1964, 19, 425-444.

2. Lintner, J. The valuation of risk assets and the selection of risky investments in stock portfolios and capital budgets. Rev. Econ. Stat. 1965, 47, 13-37. [CrossRef]

3. Acharya, V.V.; Pedersen, L.H. Asset pricing with liquidity risk. J. Financ. Econ. 2005, 77, 375-410. [CrossRef]

4. Bodie, Z.; Kane, A.; Marcus, A.J. Investment, 8th ed.; McGraw-Hill Education: New York, NY, USA, 2009.

5. Fama, E.F.; French, K.R. The Capital pricing model: Theory and Evidence. J. Econ. Perspect. 2004, 18, 25-46. [CrossRef]

6. Lucas, R.E. Asset prices in an exchange economy. Econometrica 1978, 46, 1429-1445. [CrossRef]

7. Fama, E.F.; French, K.R. Common risk factors in the returns on stocks and bonds. J. Financ. Econ. 1993, 33, 3-56. [CrossRef]

8. Aono, K.; Ivaisako, T. The consumption-wealth ratio, real estate wealth, and the Japanese stock market. Jpn. World Econ. 2013, 25, 39-51. [CrossRef]

9. Chen, M.H. Risk and return: CAPM and CCAPM. Q. Rev. Econ. Financ. 2003, 43, 369-393. [CrossRef]

10. Liu, W.; Luo, D.; Zhao, H. Transaction costs, liquidity risk and the CCAPM. J. Bank. Financ. 2015, 63, 126-145. [CrossRef]

11. Campbell, J.Y. Asset Pricing at the Millennium. J. Financ. 2002, 55, 1515-1567. [CrossRef]

12. Sonje, A.A.; Casni, A.C.; Vizek, M. The effect of housing and stock market wealth on consumption in emerging and developed countries. Econ. Syst. Res. 2014, 38, 433-450. [CrossRef]

13. Yum, K.K.; Charles, L.; Dong, J. Comparing consumption-based asset pricing models: The case of an Asian City. J. Hous. Econ. 2014, 28, 1-52.

14. Campbell, R.H.; Akhtar, S. Conditional skewness in asset pricing tests. J. Financ. 2000, 3, 1263-1295. 
15. Abhyankar, A.; Klinkowska, O.; Lee, S. Consumption risk and the cross-section of government bond returns. J. Empir. Financ. 2015, 32, 180-200. [CrossRef]

16. Okunev, J.; Wilson, P.; Zurbruegg, R. The causal relationship between real estate and stock markets. J. Real Estate Financ. Econ. 2000, 21, 251-261. [CrossRef]

17. Benjamin, J.D.; Chinloy, P.; Jud, G.D. Real estate versus financial wealth in consumption. J. Real Estate Financ. Econ. 2004, 29, 341-354. [CrossRef]

18. Parker, J.A.; Julliard, C. Consumption risk and the cross section of expected returns. J. Political Econ. 2005, 113, 185-222. [CrossRef]

19. Møller, S.V.; Rangvid, J. End-of-the-year economic growth and time-varying expected returns. J. Financ. Econ. 2015, 115, 136-154. [CrossRef]

20. Li, H. Asset pricing with long-run durable expenditure risk. Financ. Res. Lett. 2020, 32, 101176. [CrossRef]

21. Yogo, M. A consumption-based explanation of expected stock returns. J. Financ. 2006, 2, 539-580. [CrossRef]

22. Piazzesi, M.; Schneider, M.; Tuzel, S. Housing, consumption and asset pricing. J. Financ. Econ. 2007, 83, 531-569. [CrossRef]

23. Chen, G.; Hong, Z.; Ren, Y. Durable consumption and asset returns: Cointegration Analysis. Econ. Model. 2016, 53, 231-244. [CrossRef]

24. Alizadeh, S.; Shahiki Tash, M.N.; Roshan, R. The study of an adjusted CCAPM model through the Bayesian estimation of trading costs. J. Econ. Policy 2021, 12, 273-308.

25. Balcilar, M.; Demirer, R.; Bekun, F.V. Flexible time-varying betas in a novel mixture innovation factor model with latent threshold. Mathematics 2021, 9, 915. [CrossRef]

26. Peng, C.; Chen, W.; Wei, A. Teaching CAPM for a pre-finance graduate program at the STEM undergraduate level: Linear algebra perspective. Mathematics 2021, 9, 1668. [CrossRef]

27. Bostic, R.; Gabriel, S.; Painter, G. Housing wealth, financial wealth, and consumption: New evidence from micro data. Reg. Sci. Urban Econ. 2009, 39, 79-89. [CrossRef]

28. Chen, J.; Hardin III, W.; Hu, M. Housing, wealth, income and consumption: China and homeownership heterogeneity. Real Estate Econ. 2020, 48, 373-405. [CrossRef]

29. Azar, S.A. The CCAPM with varying preferences. Int. J. Bus. Manag. 2017, 12, 199-206. [CrossRef]

30. Carmichael, B.; Coën, A. Real estate and consumption growth as common risk factors in asset pricing models. Real Estate Econ. 2016, 46, 936-970. [CrossRef]

31. Dusha, E.; Janiak, A. On the dynamics of asset prices and liquidity: The role of search frictions and idiosyncratic shocks. In Society for Economic Dynamics 2018 Meeting Papers; Instituto Tecnológico Autónomo de México: Mexico City, Mexico, 2018.

32. Breeden, D. An Intertemporal Asset Pricing Model with Stochastic Consumption and Investment Opportunities. J. Financ. Econ. 1979, 7, 265-296. [CrossRef]

33. Jagannathan, R.; Wang, Y. Lazy investors, discretionary consumption, and the cross-section of stock return. J. Financ. 2007, 4, 1623-1661. [CrossRef]

34. Huh, S.; Kim, I. Real estate and relative risk aversion with generalized recursive preferences. J. Macroecon. $2021,68,103310$. [CrossRef]

35. Eiling, E.; Giambona, E.; Aliouchkin, R.; Tuijp, P. The cross-section of expected housing returns. SSRN Electron. J. 2019. Available online: https:/ / ssrn.com/abstract=331239 (accessed on 26 August 2021). [CrossRef]

36. Liu, Z.; Wang, P.; Zha, T. Land-price dynamics and macroeconomic fluctuations. Econometrica 2013, 81, 1147-1184.

37. Turid, S. Accountability and the debt crisis. Futures 1989, 21, 593-607.

38. Samii, M.V. The Oil price crisis: Economic effects and policy responses. Energy Policy 1988, 16, 527-528. [CrossRef]

39. Edwards, C. The debt crisis and development: A comparison of major economic theories. Geoforum 1988, 19, 3-28. [CrossRef]

40. Deni, W.; Alexandr, A.; Eduardo, R. The impact of bond market development on economic growth before and after the global financial crisis: Evidence from developed and developing countries. Int. Rev. Financ. Anal. 2021, 77, 101865.

41. António, A.M.; Blanco-Arana, C. Financial and economic development in the context of the global 2008-09 financial crisis. Int. Econ. 2022, 169, 30-42.

42. Ellington, M.; Florackis, C.; Milas, C. Liquidity shocks and real GDP growth: Evidence from a Bayesian time-varying parameter VAR. J. Int. Money Financ. 2017, 72, 93-117. [CrossRef]

43. Ellington, M.; Fu, X.; Zhu, Y. Real Estate Illiquidity and Returns: A Time-varying Regional Perspective. Int. J. Forecast. 2021. forthcoming. [CrossRef]

44. Baker, S.R.; Bloom, N.; Davis, S.J. Measuring economic policy uncertainty. Q. J. Econ. 2016, 131, 1593-1636. [CrossRef]

45. Guaita-Pradas, I.; Blasco-Ruiz, A. Analyzing profitability and discount rates for solar PV plants. A Spanish case. Sustainability 2020, 12, 3157. [CrossRef]

46. Lin, Q. The q5 model and its consistency with the intertemporal CAPM. J. Bank. Financ. 2021, 127, 106096. [CrossRef]

47. Ayub, U.; Kausar, S.; Noreen, U.; Zakaria, M.; Jadoon, I.A. Downside risk-based six-factor capital asset pricing model (CAPM): A new paradigm in asset pricing. Sustainability 2020, 12, 6756. [CrossRef]

48. Nasir, M.A.; Shahbaz, M.; Mai, T.T.; Shubita, M. Development of Vietnamese stock market: Influence of domestic macroeconomic environment and regional markets. Int. J. Financ. Econ. 2021, 26, 1435-1458. [CrossRef] 